\title{
A Mini-Review: Quinones and their Derivatives for Selective and Specific Detection of Specific Cations
}

\author{
Bigyan Ranjan Jali ${ }^{1}$ (D) \\ 1 Department of Technology, Veer Surendra Sai University of Technology Burla, Sambalpur-768018, Odisha, India; \\ bigyan.Jali7@gmail.com (B.R.J.); \\ * Correspondence: bigyan.Jali7@gmail.com;
}

Scopus Author ID 36503969200

Received: 14.10.2020; Revised: 11.12.2020; Accepted: 13.12.2020; Published: 16.12.2020

\begin{abstract}
The development of fluorescence and colorimetric sensors has been an active research area in the last few decades due to their wide range of environmental, agricultural, and medicinal chemistry applications. This review provides an overview of quinones' recent contribution and their derivatives to fluorescence and colorimetric sensors. It discusses their sensing properties with promising features.
\end{abstract}

Keywords: fluorescence; chemosensor; color change; UV-visible; quinone.

(C) 2020 by the authors. This article is an open-access article distributed under the terms and conditions of the Creative Commons Attribution (CC BY) license (https://creativecommons.org/licenses/by/4.0/).

\section{Introduction}

Metal plays a noteworthy role in biological, environmental, and chemical processes. , The development of potent molecular probes for selective and specific sensing of specific metal ions is an active research area in the multidisciplinary field of "Supramolecular Chemistry" [125]. It has been found that the most widely used receptor contains a signaling unit-spacerreceptor approach. In this approach, the signaling unit is linked through a covalent bond through a spacer. The signaling unit-spacer-receptor model grows up with a substantial contribution by De Silva and his research group [40]. Therefore, an ideal colorimetric and/or fluorescent molecular probe must meet two basic requirements: firstly, the receptor must have the strongest affinity with the relevant target, i.e., binding-selectivity. Secondly, because of good binding-selectivity, its signal should avoid environmental interference, i.e., signalselectivity [27]. Therefore, it is of great interest to design and synthesis the molecular probes, which properties are modified in the presence of a specific target analyte is a matter of great practical significance [28-30]. In recent reviews, Kumar et al.[36], Jose and coworkers [37] have reported various quinone receptors and their photophysical properties. Pope et al. [38] described the synthesis and electronic properties of anthraquinones. On the other hand, Skyes and Mariappan reported some examples of anthraquinone derivatives and their cation recognition properties [39]. However, no review article is available exclusively on systematic studies on quinones and their derivatives as sensors for various cations. This review gives an idea of key features of extensively studied about the quinone and its derivatives used for the specific and selective detection of specific cations.

\section{Quinones and their Derivatives as Sensors for Cations}

Quinones and their derivatives are very important molecular probes due to their various roles in colorimetric and photochemical properties [31-35]. Various fascinating binding sites, 
quinones, and their derivatives show potent molecular probes for various metal salts in the organic solvent, aqueous media, or in both aqueous-organic media. In this section, we wish to discuss various substituted based quinones and their derivatives and their cation sensing properties.

\subsection{Quinone tethered amino derivatives.}

It is well-known that amino-substituted quinone derivatives act as potent molecular probes for various metal salts such as Group-IA, IIA, transition metals, and lanthanides due to the presence of -NH groups and many binding units. The presence of specific and selective metal ions, color, and spectral change is due to ICT. It is followed by deprotonation of - $\mathrm{NH}$ moieties. Carbonyl oxygen of quinone coordinates with metal ions to affect metal-mediated photo-induced charge transfer (PCT) effects. Due to PCT effect, $n-\pi *$ transitions become higher in energy than corresponding $\pi-\pi^{*}$ transitions. They switch-ON the fluorescence [4047]. In these contexts, Kumar and coworkers have reported amino-anthraquinone derivatives 1-4, which were used for sensing transition metal ions, as shown in figure 1 [44-45].1-4 showed noticeable color change upon metal salts' addition $(\mathrm{pH} 7.0)$ in $\mathrm{CH}_{3} \mathrm{OH}-\mathrm{H}_{2} \mathrm{O}(1: 1, \mathrm{v} / \mathrm{v})$.

Receptor 1 showed absorption maxima at $494 \mathrm{~nm}$ in its UV-vis spectrum. The intensity of the absorbance band at $494 \mathrm{~nm}$ decreased with a new peak that occurred at $604 \mathrm{~nm}$ in the presence of $\mathrm{Cu}^{2+}$ ions. It caused the color change from red to blue. It is due to the $\mathrm{Cu}^{2+}$ bound selectively with three $\mathrm{N}$-atoms out of two $\mathrm{sp}^{2} \mathrm{~N}$-atom and one aryl amine $\mathrm{N}$-atom present in the receptor. However, receptor 1 did not induce any color changes and spectral changes upon other metal salts' addition. Receptor $\mathbf{2}$ displayed the absorption band at $500 \mathrm{~nm}$. The absorption band's intensities at $500 \mathrm{~nm}$ decreased, and a new band occurred at $626 \mathrm{~nm}$ in the presence of $\mathrm{Ni}^{2+}$ and $\mathrm{Co}^{2+}$. It caused the color change from red to lilac. However, a new band, the presence of $\mathrm{Cu} 2+$, occurred at $604 \mathrm{~nm}$ with a color change from red to blue.

On the other hand, the receptor remains silent towards other metal ions. It is due to the differential modes of interaction of respective metal ions. Receptor $\mathbf{3}$ showed the absorbance maxima at $400 \mathrm{~nm}$. The bathochromic shift was perceived due to the presence of $\mathrm{Cu}^{2+}, \mathrm{Ni}^{2+}$, and $\mathrm{Co}^{2+}$; it caused the change of color from yellow to brown.

On the other hand, the presence of $\mathrm{Zn}^{2+}$ led to a hypsochromic shift and color change from yellow to colorless. It is due to various coordination modes along with multiple optical responses. On continuous effort on the cation sensor, the same group has also reported anthraquinone-based receptors 5-9 based on Schiff base scaffold capable of sensing of various cations in $\mathrm{CH}_{3} \mathrm{OH} / \mathrm{HEPES}$ (4:1) medium as shown in figure 2 [48-49].
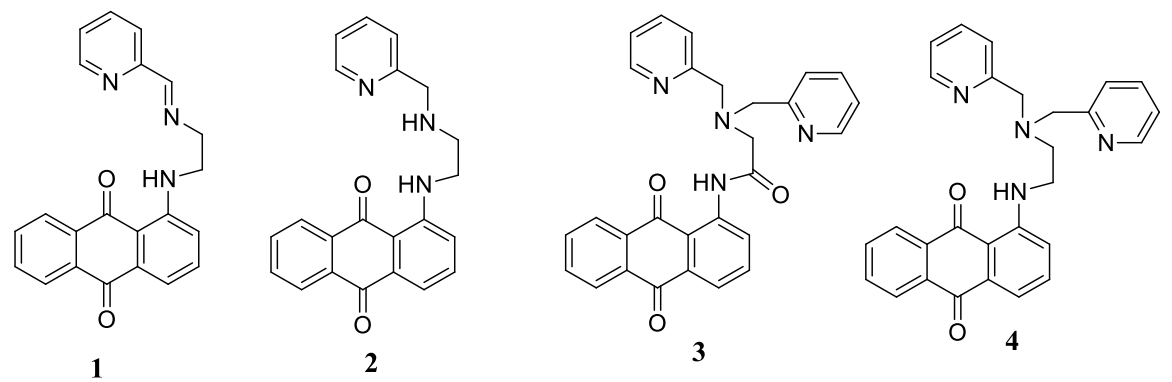

Figure 1. Receptor 1-4 used for sensing properties.

In the UV-vis spectrum, receptor 5 showed the absorbance maxima at $500 \mathrm{~nm}$. The authors found that upon addition of $\mathrm{Cu}^{2+}$ and $\mathrm{Ni}^{2+}$ to $\mathbf{5}$, the color changed from red to blue $\left(\mathrm{Cu}^{2+}\right)$ and green $\left(\mathrm{Ni}^{2+}\right)$. Upon addition of $\mathrm{Cu}^{2+}$, a large red shift $(100 \mathrm{~nm})$ from absorption maxima 
500 to $600 \mathrm{~nm}$ takes place but $\mathbf{5}$, displayed a mega red shift $(250 \mathrm{~nm})$ from absorption maxima 500 to $750 \mathrm{~nm}$ in the presence of $\mathrm{Ni}^{2+}$ and a new absorption band formed at $385 \mathrm{~nm}$ [48]. Due to the existence of amino-anthraquinone moiety and the hydroxyl-naphthalene group, receptor 6 ascribed two absorbance peaks at 500 and $415 \mathrm{~nm}$, respectively. In the presence of $\mathrm{Cu}^{2+}$ to $\mathbf{6}$, a new absorption peak at $600 \mathrm{~nm}$ was observed and associated with the color alteration from red to blue. The authors attributed that the red shift occurred due to the deprotonation of - $\mathrm{NH}$ groups. In the presence of $\mathrm{Ni}^{2+}$, the absorbance bands at 500 and $415 \mathrm{~nm}$ diminished along with two new absorption bands raised at $445 \mathrm{~nm}$ and $700 \mathrm{~nm}$, respectively. The new absorbance band was ascribed due to the deprotonation of both - $\mathrm{NH}$ and $-\mathrm{OH}$ moiety. The receptor remains silent towards other metal salts. Unlike receptor 6, receptors 7 showed an absorbance band at $485 \mathrm{~nm}$ and $435 \mathrm{~nm}$, respectively, and 8 showed an absorbance band at $492 \mathrm{~nm}$. Both the receptors $\mathbf{7}$ and 8 found selectively renowned $\mathrm{Cu}^{2+}$. With the addition of $\mathrm{Cu}^{2+}$ to $\mathbf{7}$ and $\mathbf{8}$, a large red shift (100 nm) was observed. It caused the color change from red to blue. Receptor 9 showed absorbance maxima at $530 \mathrm{~nm}$. In the presence of $\mathrm{Co}^{2+}$, the absorbance band at 530 $\mathrm{nm}$ was quenched, and two new peaks at 365 and $700 \mathrm{~nm}$ appeared. It caused the color change to take place from purple to blue. However, in the presence of $\mathrm{Ni}^{2+}, 9$ formed a new broad peak between 700-780 nm, and the purple color goes to blue. The authors suggested that receptor 9 was used for the molecular level information-processing device due to its different optical behaviors [49].

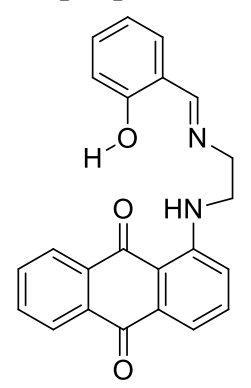

5

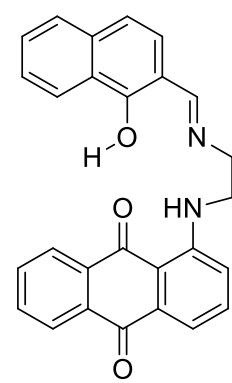

6

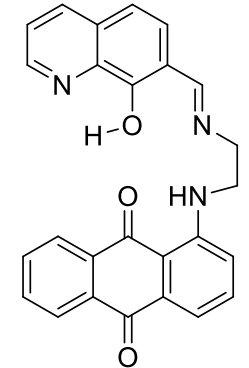

7

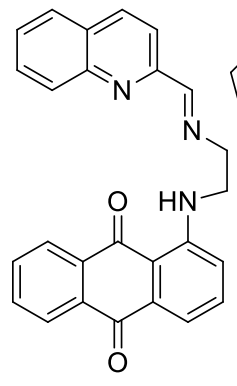

8

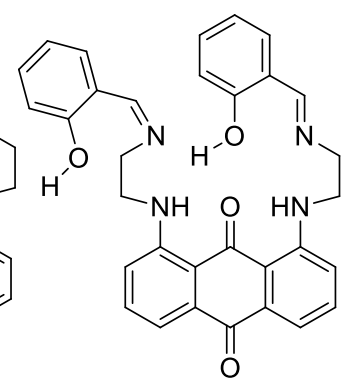

9

Figure 2. Receptor 5-9 used for sensing properties.

Kaur et al. reported the character of $\mathrm{Cu}^{2+}$ ions in amino-anthraquinone derivatives 1012 by using UV-vis spectra $\left(\mathrm{CH}_{3} \mathrm{OH}-\mathrm{H}_{2} \mathrm{O} 3: 1 \mathrm{v} / \mathrm{v}\right)$ at $\mathrm{pH}$ 7. Receptor 10 showed absorbance maxima at $512 \mathrm{~nm}$. The absorbance band at $512 \mathrm{~nm}$ gradually decrease, and a new peak appeared at $620 \mathrm{~nm}$, and the red color solution turns to blue in the presence of $\mathrm{Cu}^{2+}$. The authors reported that the appearance of a new peak at a higher wavelength due to the formation of 10$\mathbf{C u}^{2+}$ complex. However, $\mathbf{1 1}$ was selectively sensing $\mathrm{Cu}^{2+}$ ions amongst other metal salts. The authors suggested that the 10-11- $\mathbf{C u}^{2+}$ complexes were stable up to $\mathrm{pH}$ range 4.5-11; at the same time, 11- $\mathrm{Cu}^{2+}$ fragmented to give the free receptor and $\mathrm{Cu}(\mathrm{OH})_{2}$ [48]. In contrast, receptor 12 showed the absorbance band at $492 \mathrm{~nm}$, which was quenched on reacting with of $\mathrm{Cu}^{2+}$ (1 equiv.) with a new peak raised at $615 \mathrm{~nm}$. This resulted that the red color solution becomes blue [50]. On continuous effort on their colorimetric chemosensor, the same group also reported anthraquinone-based receptors (13a-c); these receptors showed selective towards $\mathrm{Cu}^{2+}$ in the presence of other metal salts [52]. The receptors 13a-b showed absorbance maxima at $492 \mathrm{~nm}$. In the presence of $\mathrm{Cu}^{2+}$ ions, new absorption bans have occurred at $600 \mathrm{~nm}$, and the red color solution goes to blue. The authors found that the selectivity $\mathrm{Cu}^{2+}$ towards the receptor $\mathbf{1 3 a}-\mathbf{b}$ is due to its highest lewis acid character [53]. The receptors 14a-c showed absorbance maxima at $535 \mathrm{~nm}$. In the presence of $\mathrm{Cu}^{2+}, \mathbf{1 4 a}-\mathbf{b}$, decreased the absorbance band's intensities 
at $535 \mathrm{~nm}$, and two new absorption bands at $715 \mathrm{~nm}$ and $800 \mathrm{~nm}$ were observed. The magenta

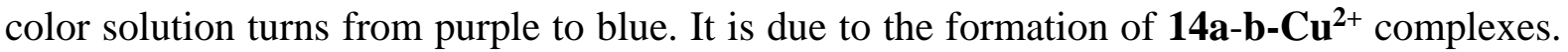
The receptor $\mathbf{1 4 c}$ remains silent towards other metal ions, and as well as no color or absorbance change takes place with $\mathrm{Cu}^{2+}$ ion [51]. The receptors 15a-c exhibited an absorption band at 585 $\mathrm{nm}$ and $630 \mathrm{~nm}$, respectively. Two new absorption bands raised at around $665 \mathrm{~nm}$ in the presence of $\mathrm{Cu}^{2+}$ and blue color turn to turquoise blue for $\mathbf{1 5 a} \mathbf{a}-\mathbf{b}$. The receptor $15 \mathbf{c}$ remains silent towards other metal salts, as shown in figure 3 [54].

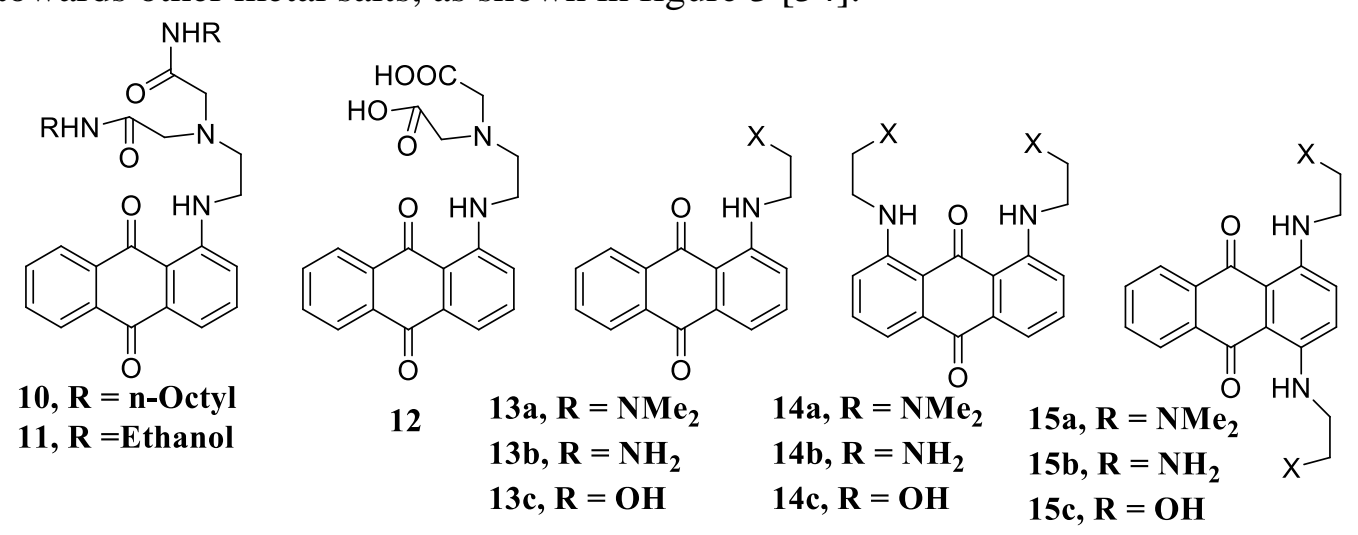

Figure 3. Receptor 10-15 used for sensing properties.

Ermakova and coworkers have reported the receptors 16a-b, based on 1,8-diaminoanthraquinone derivatives containing phosphonic acid esters. Both receptors showed selective detection of $\mathrm{Hg}^{2+}$, as shown in figure 4. The receptor 16a showed an absorbance band at 561 $\mathrm{nm}$. It is due to ICT. The receptor showed an absorption peak at $56 \mathrm{~nm}$. The absorption quenched with the appearance of a new peak at $509 \mathrm{~nm}$ on interacting with $\mathrm{Hg}^{2+}$ (5 equiv.), and blue color goes to pink in color. However, 16a remains silent towards other metal salts. The receptor $16 \mathrm{~b}$ showed absorbance maxima at $565 \mathrm{~nm}$. The intensities of absorption peak quenched, and the blue-violet color goes pink in color in the presence of $\mathrm{Hg}^{2+}$ (5 equiv.) [55]. On continuous work on amino-anthraquinone derivatives containing phosphonic acid esters, Guilard et al. reported water-soluble colorimetric chemosensor $\mathbf{1 7 c - f}$.

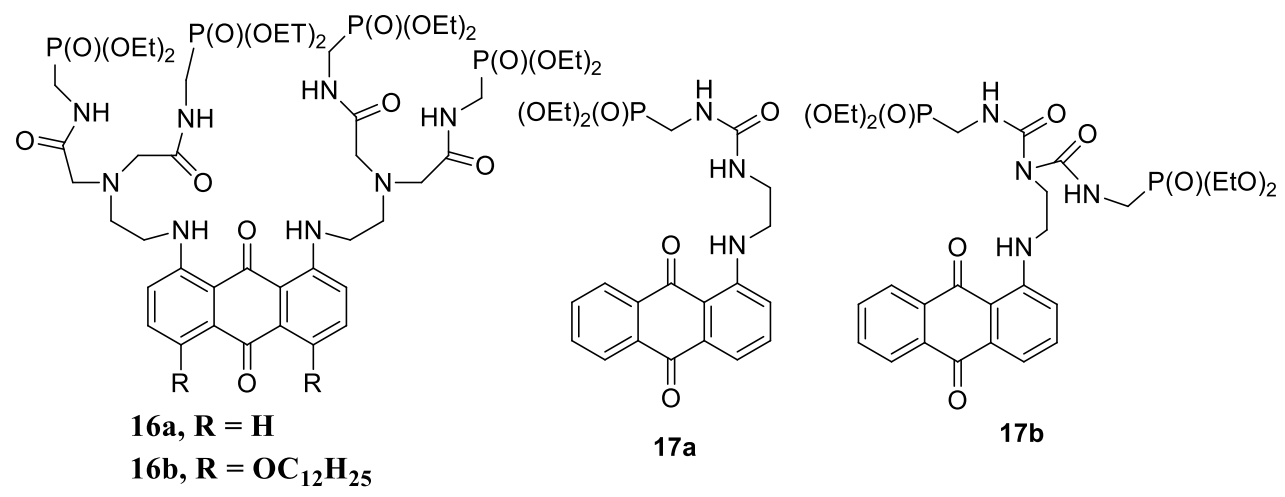

Figure 4. Receptor 16-17a-b used for sensing properties.

All the synthesized receptors were able to detect $\mathrm{cu}^{2+}$ over other metal salts and produced color change [52]. Anthraquinone unit has also been incorporated into the macrocyclic backbone to develop selective sensors resulting from additional coordination groups' simple attachment to the respective macrocycle. Guilard and his research group synthesized a series of 1,8-diaminoanthraquinone based poly-azamacrocycles $\mathbf{1 8}$ and 19a-b and studied their cation binding affinities. Receptor 18 showed absorbance maxima at $562 \mathrm{~nm}$. 
The presence of $\mathrm{Cu}^{2+}$ to $\mathbf{1 8}$ showed a bathochromic shift $(\Delta \lambda=94 \mathrm{~nm})$ in its absorption band. In contrast, a hypsochromic shift $(\Delta \lambda=26 \mathrm{~nm})$ was observed upon the addition of $\mathrm{Al}^{3+}$. The receptor 19a detected $\mathrm{Cu}^{2+}$ and $\mathrm{Pb}^{2+}$ in $\mathrm{DMSO}-\mathrm{H}_{2} \mathrm{O}(1: 1)$, showed color changes from violet to pink for $\mathrm{Pb}^{2+}$ and blue for $\mathrm{Cu}^{2+}$.

On the other hand, for $\mathbf{1 9 b}$, the violet color turns to pink. The hypsochromic shift $(\Delta \lambda$ $=30 \mathrm{~nm})$ in the presence of $\mathrm{Pb}^{2+}$ and a bathochromic shift $(\Delta \lambda=103 \mathrm{~nm})$, and the violet color turns to blue on the addition of $\mathrm{Cu}^{2+}$. The authors attributed that the hypochromic shifts were raised due to the conformational changes. The bathochromic shift resulted from the deprotonation of the - $\mathrm{NH}$ of the receptor, as shown in figure 5 [56]. Kumar and coworkers have reported the metal ion sensing ability of quinone receptor $\mathbf{2 0}$ containing an $\mathrm{N}, \mathrm{N}$-dimethyl group [57]. Receptor 20 showed absorbance maxima at $436 \mathrm{~nm}$. The absorption band's intensities quenched with the appearance of a new peak at $520 \mathrm{~nm}$ with a yellow-green color turn to pink in the presence of $\mathrm{Cu}^{2+}$ (10 equiv.). The authors attributed that the red shift of absorbance maxima was due to deprotonation of $\mathrm{NH}$-amine, and quenched fluorescence occurred due to LMCT.

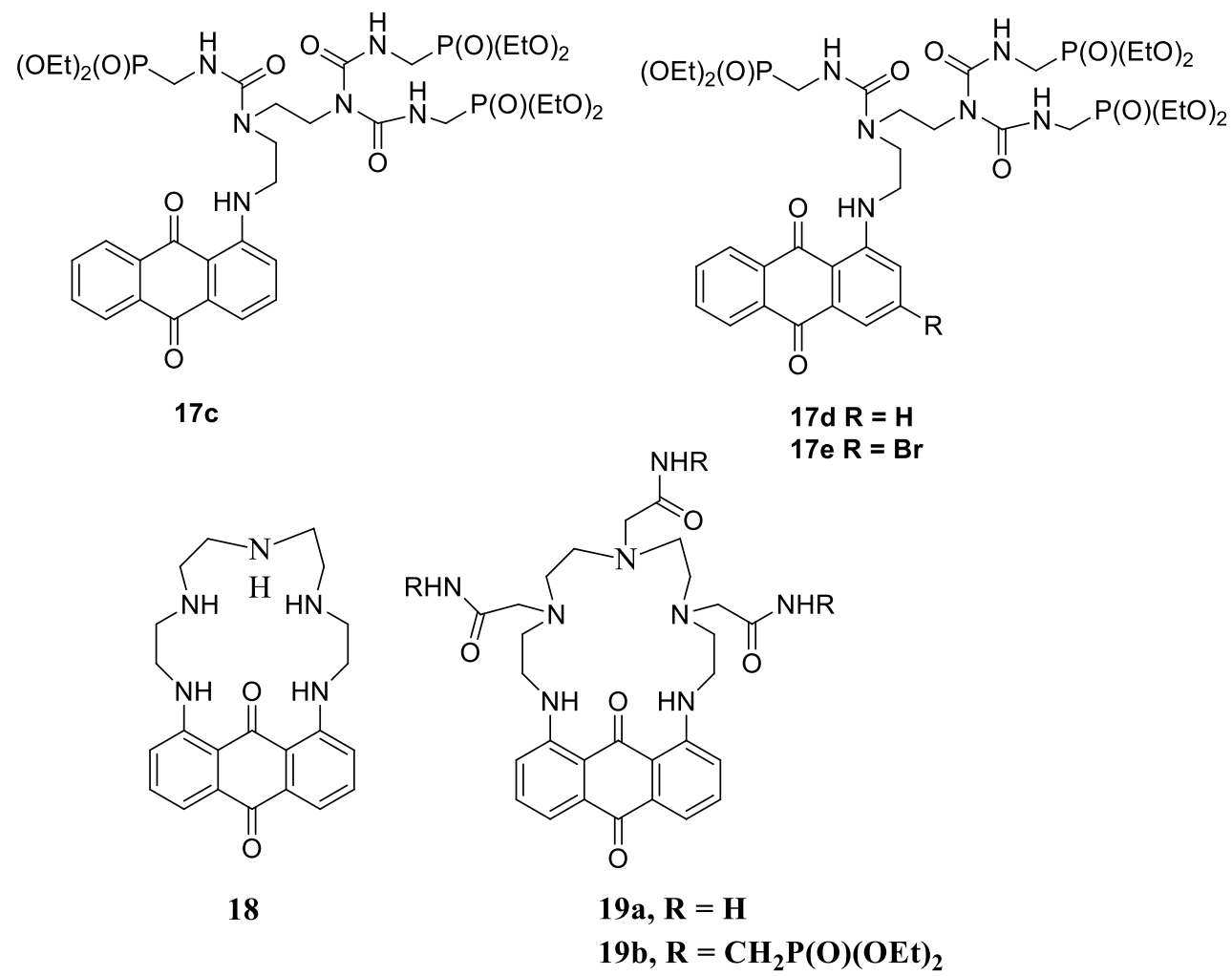

Figure 5. Receptor 17c-19 used for sensing properties.

$\mathrm{Wu}$ and his research group have reported a few amino-anthraquinone receptors 21-22 [58]. Both receptors were used for selective colorimetric chemosensor for various metal ions in $\mathrm{CH}_{3} \mathrm{OH}$ : HEPES (4:1) using UV-vis spectra. In the presence of $\mathrm{Cu}^{2+}$, a bathochromic shift $(\Delta \lambda=76 \mathrm{~nm}$ from $397 \mathrm{~nm}$ to $473 \mathrm{~nm})$ yellow color solutions of 21-22 turn to dark-red. The bathochromic shifts are due to the deprotonation of - $\mathrm{NH}$ group of receptors. The receptor $\mathbf{2 1}$ remains silent towards other cations. Whereas $\mathrm{Ni}^{2+}$ to 22 ascribed a red shift of $86 \mathrm{~nm}$ and yellow color solutions turn to red. However, in the presence of $\mathrm{Co}^{2+}, 22$ displayed a blue shift, and the yellow color turns to pale green. The authors found that receptor $\mathbf{2 2}$ did not respond to any color changes on treatment with group-IA, group-IIA, and other transition metal ions. 2Methyl-1,4-naphthoquinone based chemosensor 23-24 selective detection of $\mathrm{Cu}^{2+}$ amongst various metal salts. This is attributed to the requisite of $\mathrm{Cu} 2+$ to $-\mathrm{NH}$ groups, which induce 
deprotonation of - $\mathrm{NH}$ units to cause the observed color change. The same groups have reported the receptors 23 and 24 based on the pyridine scaffold capable of selectively binding $\mathrm{Cu} 2+$ ions [59] on continuous effort on colorimetric chemosensor. In UV-vis spectra, both receptors underwent a color change from orange to dark blue and a $168 \mathrm{~nm}$ red shift on the addition of $\mathrm{Cu}^{2+}$ as shown in figure 6 .<smiles>CN(C)CCNc1c2c3c(cccc3[nH]c1=O)C(=O)c1ccccc1-2</smiles>

20<smiles>O=C(CNCc1ccccc1)Nc1cccc2c1C(=O)c1ccccc1C2=O</smiles>

21<smiles>O=C1c2ccccc2C(=O)c2c(NCC/N=C/c3ccccn3)cccc21</smiles>

22<smiles>CC1=C(NCc2ccccn2)C(=O)c2ccccc2C1=O</smiles>

23<smiles>CC1=C(NCCc2ccccn2)C(=O)c2ccccc2C1=O</smiles>

24

Figure 6. Receptor 20-24 used for sensing properties.

Yang et al. reported the cation sensing ability of a series of anthraquinone derivatives 25a-d based on urea and thiourea group at 1,2-positions, as shown in figure 7 [60-61]. These derivatives exhibited naked eye visible color change in $\mathrm{DMSO}-\mathrm{CH}_{3} \mathrm{CN}(1: 9$, v/v) medium. With electron-withdrawing groups (such as NO2) in 25a-b, the color changes have occurred. UV-vis titrations showed that in the presence of $\mathrm{Hg}^{2+}, \mathbf{2 5 a}$, underwent a blue shift of $58 \mathrm{~nm}$ from absorption band 458 to $400 \mathrm{~nm}$, and aurantium color changes to yellow. However, the absorption at $400 \mathrm{~nm}$ broadened. A new peak appeared at $650 \mathrm{~nm}$ in the presence of $\mathrm{Ag}+$ and golden color changes orange-red. Kim and his research groups have reported receptors 26-27 to detect $\mathrm{Cu}^{2+}$ in $\mathrm{ACN}$ medium.<smiles>[X]C(=Nc1ccc2c(c1NC([X])Nc1ccc([R])cc1)C(=O)c1ccccc1C2=O)Nc1ccc([R])cc1</smiles>

25a, $\mathrm{X}=\mathrm{S}, \mathrm{R}=\mathrm{NO}_{2}$

25b, $X=\mathrm{O}, \mathrm{R}=\mathrm{NO}_{2}$<smiles>C=C(C(=O)c1ccccc1)C(=CC)CNCCNC(=S)Nc1ccccc1</smiles>

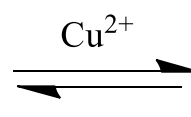

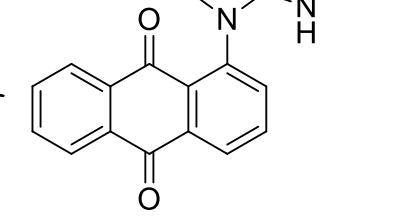

26

$25 \mathrm{c}, \mathrm{X}=\mathbf{O}, \mathbf{R}=\mathbf{H}$

25d, $X=\mathbf{O}, \mathbf{R}=\mathrm{NMe}_{2}$

Figure 7. Receptor 25-26 used for sensing properties.

In UV-vis spectra, 131 displayed absorption maxima at $500 \mathrm{~nm}$. The intensities of absorption quenched with the appearance of a new peak at $450 \mathrm{~nm}$, and the red color solution of 26 goes to pale yellow. In fluorescence titration, in the presence of $\mathrm{Cu}^{2+}$ to the solution of 26, resulting in a blue shift emission at $590 \mathrm{~nm}$ to $555 \mathrm{~nm}$. The authors found that the blue shift is due to the desulfurization process. However, 27 showed a very weak fluorescence emission and on treatment with $\mathrm{Cu}^{2+}$ showed enhancement of fluorescence at $560 \mathrm{~nm}$. Red color solutions change to yellow [62]. Anthraquinonoidalcalix-[4]-arene receptors 28a selectively 
recognized $\mathrm{Zn}^{2+}$ ions over other metal salts [63]. 28a showed excellent selectivity for $\mathrm{Zn}^{2+}$ ions over other transition metal ions.
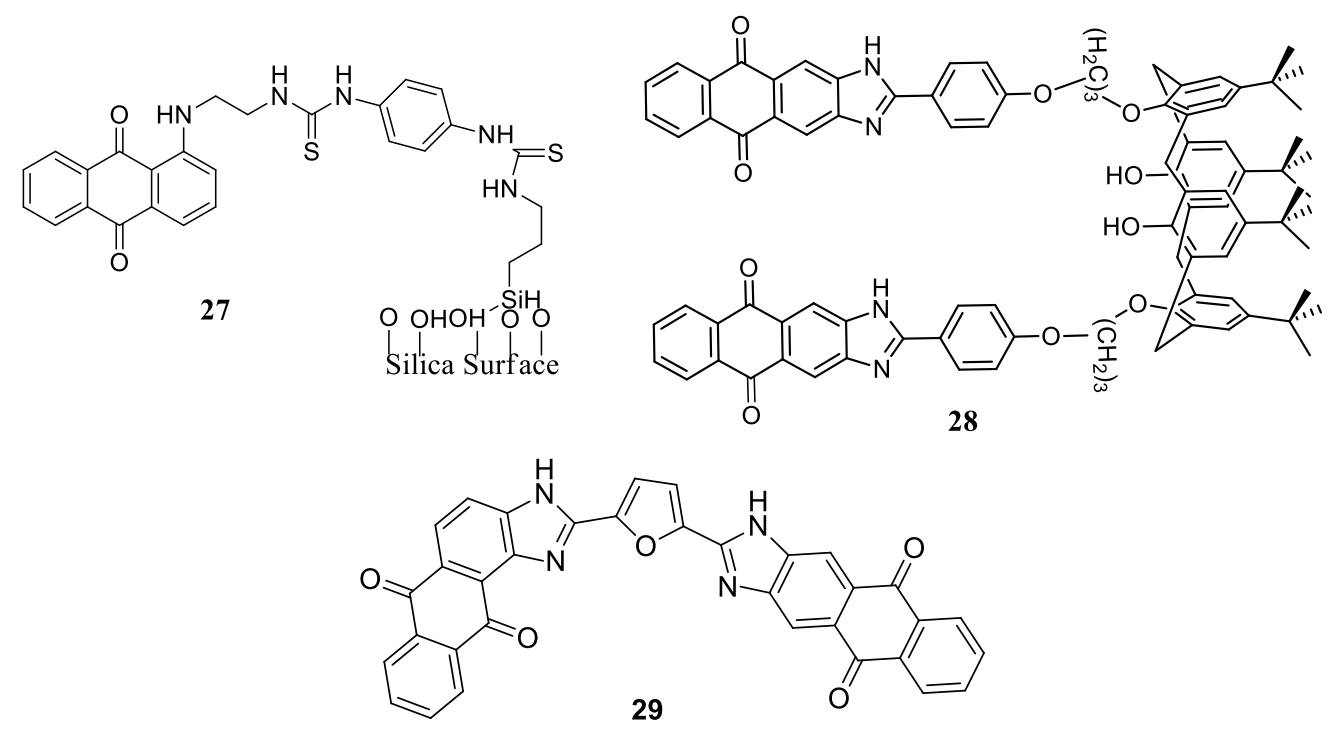

Figure 8. Receptor 27-29 used for sensing properties.

Kim and his research group described an anthraquinone tethered imidazole derivatives 29 [63]. Receptor 29 exhibited selective detection of $\mathrm{Pd}^{2+}$ and $\mathrm{Pd}^{0}$. The authors found that the selective detection of $\mathrm{Pd}^{2+}$ is due to the ligand to metal transition. In contrast, selective detection of $\mathrm{Pd}^{0}$ occurred due to metal to ligand transition excitation, as shown in figure 8 . Receptor (30a-b), based on an azacrown-anthraquinone derivative, showed detection of groupIA and group-IIA metal salts preferentially. Both receptors remain silent towards transition metal, a lanthanide metal, an actinide metal salts. Both receptors exhibited a very weak emission band at $515 \mathrm{~nm}$. The weak fluorescence is due to the PET processes [64]. Kim and his research group designed an ESIPT based chemosensor receptor 31, which showed selective and sensitive fluorescent change with $\mathrm{In}^{3+}$, among other metal salts in $\mathrm{CH}_{3} \mathrm{CN}$ solution. With the gradual addition of $\operatorname{In}^{3+}$ to 31, the fluorescence emission peak quenched with the concomitant appearance of a new blue-shifted peak due to segregation of the intramolecular $\mathrm{H}$ bond formation. The differential pulse CV studies were also conducted wherein the two cathodic peaks of $\mathbf{3 1}$ disappeared upon the addition of $\operatorname{In}^{3+}$. An additional cathodic peak was observed from the reduction process of $\mathbf{3 1}: \mathrm{In}^{3+}$ complex, as shown in figure 9 [65-66].
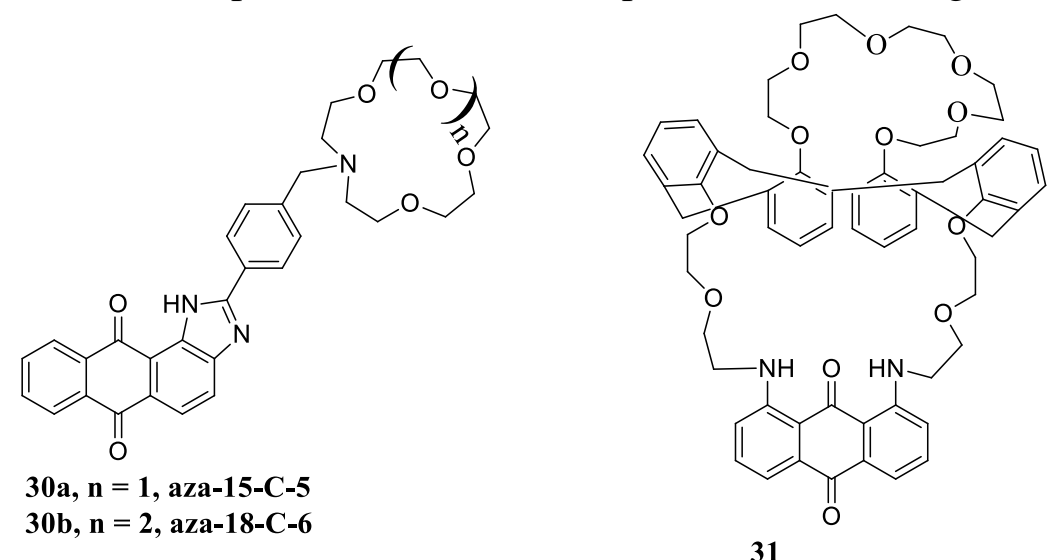

Figure 9. Receptor 30-31 used for sensing properties.

Receptor 32, based on a zinc porphyrin-quinone linked derivative capable for selective detection $\mathrm{Y}^{3+}$ ions amongst other metal salts. The authors attributed that weak fluorescence of 
32 was due to the electron-transfer from metal ions to 32 [67-68]. Gawali and his research group reported a series of bromine substituted amino-naphthoquinones (33-37) and examined their colorimetric sensing properties with various metal salts. The orange color turns to blue for $\mathbf{3 3}$ and dark green for $\mathbf{3 4}$ upon the addition of $\mathrm{Cu}^{2+}$. This occurred due to deprotonation of -NH proton; however, receptors 35-37 remain silent towards other metal ions [69]. However, Elango et al. reported a naphthoquinone tethered amino triazole derivative 38, which was selectively recognized as $\mathrm{Hg}^{2+}$ ions. The receptor showed absorption maxima at $445 \mathrm{~nm}$. It is due to $\mathrm{n}-\pi^{*}$ transition. In the presence of $\mathrm{Hg}^{2+}$, the absorption intensities gradually quenched, and a new peak appeared at $569 \mathrm{~nm}$.

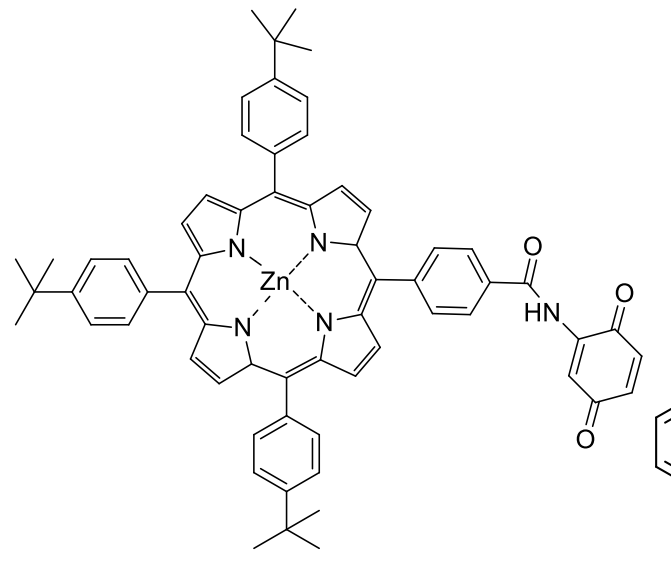

32<smiles>O=C1C(Br)=C(NCc2ccccn2)C(=O)c2ccccc21</smiles>

33<smiles>O=C1C(Br)=C(NCc2cccnc2)C(=O)c2ccccc21</smiles>

34<smiles>O=C1C(Br)=C(NCc2cccs2)C(=O)c2ccccc21</smiles>

35<smiles>O=C1C(Br)=C(NCCc2cccs2)C(=O)c2ccccc21</smiles>

36<smiles>O=C1C(Br)=C(NCCc2ccccn2)C(=O)c2ccccc21</smiles>

37<smiles>O=C1C(Cl)=C(Nc2nccs2)C(=O)c2ccccc21</smiles>

38

Figure 10. Receptor 32-38 used for sensing properties.

With the gradual addition of $\mathrm{Hg}^{2+}$ to $\mathbf{3 8}$, an isosbestic point at $483 \mathrm{~nm}$ has appeared. It caused the color change from pale brown to blue. The fluorescence titrations showed the receptor form a 1: 1 complex with $\mathrm{Hg}^{2+}$ with moderate binding constant $\mathrm{Ka}=3.5 \times 10^{4} \mathrm{M}^{-1}$. The detection limit was found to be $0.3 \mu \mathrm{M}$. The authors found that the receptor was selectively recognized $\mathrm{Hg}^{2+}$ ions, which was lower than the permissible limit in the drinking water given by WHO [69] in figure 10. Baruah et al. reported a series of pyridine tethered 1,4naphthoquinone derivatives (39-42) and exhibited their sensing properties by using UV-vis and fluorescence titrations, as shown in figure 11.<smiles>O=C1C=C(NCc2ccccn2)C(=O)c2ccccc21</smiles>

39<smiles>O=C1C=C(NCc2cccnc2)C(=O)c2ccccc21</smiles>

40<smiles>O=C1C=C(NCc2ccncc2)C(=O)c2ccccc21</smiles>

41<smiles>O=C1C=C(NCCc2ccccn2)C(=O)c2ccccc21</smiles>

42

Figure 11. Receptor 39-42 used for sensing properties.

Receptor 39 displayed absorption maxima at $438 \mathrm{~nm}$ in methanol. Upon excitation, 445 $\mathrm{nm}$ emission peak appeared at $538 \mathrm{~nm}$, which was attributed to $\pi^{*}-\pi .39$ showed high selectivity 
towards $\mathrm{Mn}^{2+}$ ions. However, receptor 40 showed highly selective for $\mathrm{Cd}^{2+}$ ions (OFF-ON-ON) over other metal ions. It is due to the interaction between $\mathrm{Cd}^{2+}$ ions and $\mathbf{4 0}$ [70].

\subsection{Alkoxy based receptors.}

Wang and his research groups have reported a $\mathrm{Cu}^{2+}$ sensor by forming an inclusion complex of $\mathbf{4 3}$ with $\beta$-CD in an aqueous medium [71]. The aqueous solution of receptor $\mathbf{4 3}$ envisages three distinct forms - the yellow color in a neutral medium; pink in dilute alkali (due to anionic state). In the case of a strong alkali medium (due to di-anionic state), shows deep blue color was observed in aqueous media. The authors found that the absorption and fluorescence intensities of $\mathbf{4 3}$ were enhanced by $\beta$-CD. The presence of ammonia molecule, the 43: $\boldsymbol{\beta}$-CD complex, showed selective toward $\mathrm{Cu}^{2+}$ ions amongst other cations. It resulted in color change, and chelation enhanced quenching (CHEQ). The presence of lone pair of an electron in a nitrogen atom plays an important role in the formation of the complex with $\mathrm{Cu}^{2+}$

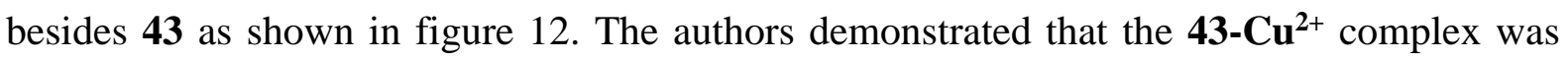
formed by binding through the carbonyl $(-\mathrm{C}=\mathrm{O})$ and $\mathrm{O}$-atom of hydroxyl unit $(-\mathrm{OH})$ and two ammonia molecules. Thus, ammonia acted as both bases as well as a ligand. It was applicable for the determination of $\mathrm{Cu}^{2+}$ in tap and river water samples and in tea. Kar and coworkers [72] used alkoxy-anthraquinone-based receptors $\mathbf{4 4 a - b}$ for selective recognition of alkali earth metals (Group-IIA), amongst other metal ions. Both receptors showed absorbance maxima at $278 \mathrm{~nm}$ and $427 \mathrm{~nm}$, respectively. The absorption band at $427 \mathrm{~nm}$ was raised because of charge transfer from $-\mathrm{OH}$ or $-\mathrm{OCH}_{3}$ (donor) units to anthraquinone (acceptor) unit. In the presence of $\mathrm{Mg}^{2+}$, a new absorption band was raised in 500-575 nm, and the yellow color turns to red. The color and spectral change occurred due to the formation of complexes between the metal and receptors.

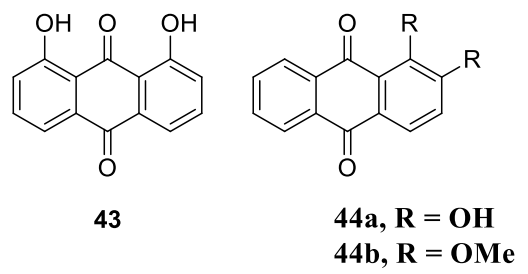

Figure 12. Receptor 43-44 used for sensing properties.

Shamsipur and coworkers have studied the role of $\mathrm{Cu}^{2+}$ ions in anthraquinone derivatives 45 by using UV-vis and fluorescence titrations [73]. Receptor 45 was used for the selective detection of $\mathrm{Cu}^{2+}$ ions in black tea samples. Similarly, diester-anthraquinone conjugate receptor $\mathbf{4 6}$ for selective detection of $\mathrm{Li}^{+}$and $\mathrm{Na}^{+}$ions over other metal salts was reported by Jeon et al. The authors found that the derivative showed red shift for $\mathrm{Li}^{+}$and $\mathrm{Na}^{+}$ [74]. 9,10-anthraquinone based 2-aminothiophenol derived receptors $\mathbf{4 7 a - b}$ were found to be selective $\mathrm{Cu}^{2+}$ reported by Kaur et al. in the presence of $\mathrm{Cu}^{2+}, \mathbf{4 7 \mathbf { b }}$ showed a new absorption band around 520-800 $\mathrm{nm}$ with light yellow color turns to brown. The addition of divalent cations did not affect the absorption spectrum of $\mathbf{4 7 b}$. This indicates that the presence of $\mathrm{NH}_{2}$ is a requirement to form a chelated complex to show the change in color by this series of the receptor [75]. Sykes and coworkers [76] developed a $\mathrm{Cu}^{2+}$ and $\mathrm{Fe}^{3+}$ sensor $\mathbf{4 8}$. The addition of $\mathrm{Cu}^{2+}$ or $\mathrm{Fe}^{3+}$ to 48 led to a 20 fold enrichment of fluorescence emission, resulting in red-orange fluorescence color. It is due to the formation of 49. The same groups have also designed and synthesized a series of anthraquinone containing cyclic and acyclic polyether receptors 50-52 
[77-78] on continuous effort on cation sensing. All synthesized receptors governed 1:1 complexes with hydronium ion, as shown in figure 13.<smiles>[X]c1ccccc1SCCOc1cccc2c1C(=O)c1c(OCCSc3ccccc3[X])cccc1C2=O</smiles><smiles>CC(C)(C)C(=O)CCCOc1cccc2c1C(=O)c1cccc(OCC[Se]c3ccccc3)c1C2=O</smiles><smiles>COC1OCCOCCOc2cccc3c2C(=O)c2c(cccc21)C3=O</smiles>

50<smiles>COCCOC(=O)c1cccc2c1C(=O)c1c(OCCOCOC)cccc1OCCO2</smiles>

51<smiles></smiles>

52

Figure 13. Receptor 45-52 used for sensing properties.<smiles>[Y4]CCCOc1cccc2c1C(=O)c1c(OCCN[Y4])cccc1C2=O</smiles>

53a, $X_{1}=X_{3}=S, X_{2}=0$

$53 b, X_{1}=X_{2}=X_{3}=S$<smiles>O=C1C(=Nc2ccccc2)c2cccc(OCCOCCOCCO)c2C(=O)C2=C1OCCOCCOCCOCCOCCOCCOCCOCCO2</smiles>

54

Figure 14. Receptor 53-54 used for sensing properties.

The receptor $\mathbf{5 0}$ displayed selective sensing of $\mathrm{Pb}^{2+}$ and $\mathrm{Ca}^{2+}$ in acetonitrile solution. Upon addition of $\mathrm{Pb}\left(\mathrm{ClO}_{4}\right)_{2}$ and $\mathrm{Ca}\left(\mathrm{ClO}_{4}\right)_{2}, \mathbf{5 0}$ displayed bathochromic shift $(\Delta \lambda=20 \mathrm{~nm})$ from absorption band 380 to $400 \mathrm{~nm}$. The bathochromic shift was raised due to the replacement of non-radiative transitions by radiative transitions. Sykes and his research groups have also reported sulfur-containing anthraquinone derivatives 53a-b and examined their metal ion sensing properties in acetonitrile solution using UV-vis spectra, as shown in figure 14 [79]. 
The authors found that both receptors were used for selective recognition of $\mathrm{Cd}^{2+}$ and $\mathrm{Hg}^{2+}$ in acetonitrile. The receptor 53a showed a bathochromic shift $(\Delta \lambda=14 \mathrm{~nm}) \mathrm{nm}$ from absorption band 388 to $402 \mathrm{~nm}$ on the addition of $\mathrm{Cd}^{2+}$, and the emission band occurred at $506 \mathrm{~nm}$ on reacting with $\mathrm{Cd}^{2+}$ ions.

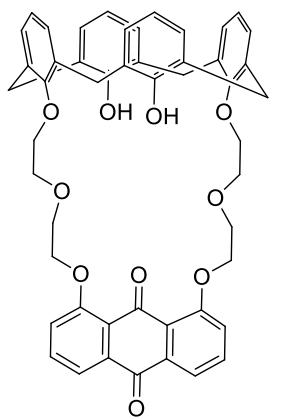

$55 \mathbf{a}$
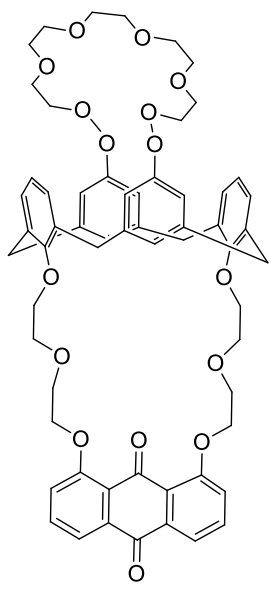

$55 b$

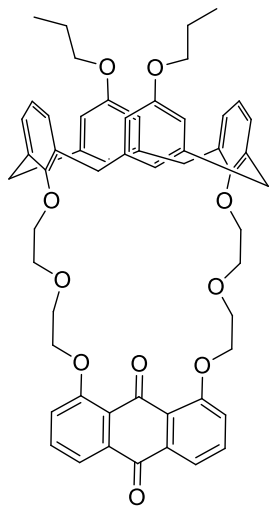

$55 \mathrm{c}$

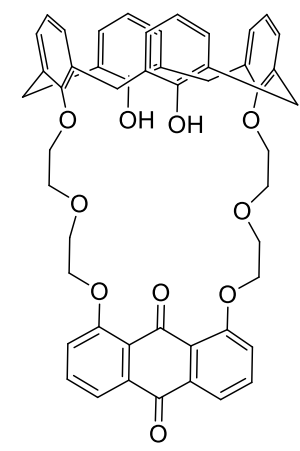

$55 a$

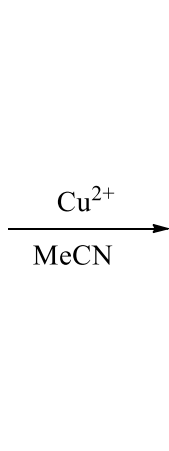

$\underset{\mathrm{MeCN}}{\stackrel{\mathrm{Cu}^{2+}}{\longrightarrow}}$

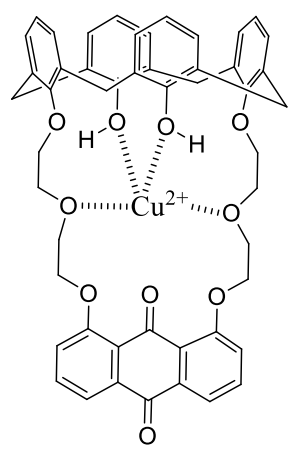

$55 \mathbf{a}+\mathrm{Cu}^{2+}$

Figure 15. Receptor 55 a-c used for sensing properties.

However, the receptor $\mathbf{5 3 b}$ showed a bathochromic shift $(\Delta \lambda=16 \mathrm{~nm})$ from the absorption band 390 to $406 \mathrm{~nm}$ on the addition of $\mathrm{Hg}^{2+}$ ion. The enhancement fluorescence was observed at $520 \mathrm{~nm}$ was observed in the presence of $\mathrm{Hg}^{2+}$ ions. In another case, the same research group also reported a potent molecular probe $\mathbf{5 4}$, as shown in figure 14, which was selective detection of $\mathrm{Ba}^{2+}$ amongst other metal ions. Coordination of $\mathrm{Ba}^{2+}$ ions to nitrogen atom lone pairs restricted the rotation around the $\mathrm{C}=\mathrm{N}$ groups, thus, inhibiting the isomerization and consequent activation of the luminescence resulting in enhanced emission [80]. Calix-[4]anthraquinone receptor 55a-c was used for selective recognition of $\mathrm{Cu}^{2+}$ ions amongst other metal ions. 55a showed bathochromic shift $70 \mathrm{~nm}$, and yellow color solutions go to red color in the presence of $\mathrm{Cu}^{2+}$ ions in acetonitrile solution. The authors suggested that ICT played an important role in forming complexes between 55a and $\mathrm{Cu}^{2+}$ ions [81]. Receptors 55b-c did not respond to any color change and spectral change towards $\mathrm{Cu}^{2+}$ and other cations due to the absence of two proximal -OH groups, as shown in figure 15.

They have also reported an anthraquinone based receptor 56 possessing 1,2,3-triazoles; the receptor was used to detect $\mathrm{Al}^{3+}$ over other metal ions [82]. The addition of $\mathrm{Al}^{3+}$ ions to $\mathbf{5 6}$ showed a bathochromic shift of $120 \mathrm{~nm}$. From the fluorescence profile, enhancement of fluorescence was observed in the presence of $\mathrm{Al}^{3+}$. The bathochromic shift and enhanced fluorescence occurred due to ICT and chelation enhanced fluorescence. It resulted as $\mathrm{Al}^{3+}$ led complex with $\mathbf{1 6 0 .}$ 
On the other hand, receptor 57 was capable of detecting $\mathrm{Cu}^{2+}$. In the presence of $\mathrm{Cu}^{2+}$, a bathochromic shift of $70 \mathrm{~nm}$ was observed. The quenched fluorescence was occurred due to the paramagnetic nature of $\mathrm{Cu}^{2+}[83]$.

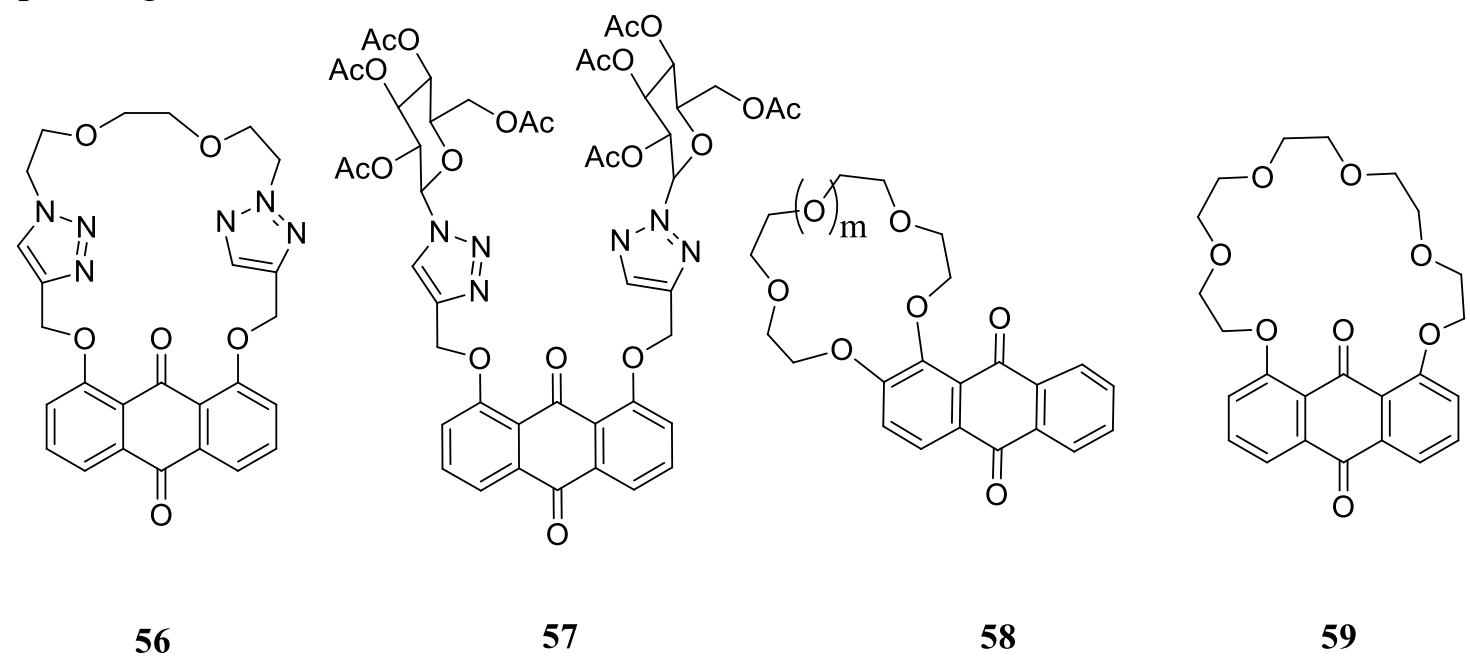

Figure 16. Receptor 56-59 used for sensing properties.

Erkand and his coworkers have reported anthraquinone-based receptors 58-59, which were capable of binding $\mathrm{Li}^{+}$over other metal salts. Receptor $\mathbf{5 9}$ showed absorption bands at $373 \mathrm{~nm}$ and $333 \mathrm{~nm}$ in the presence of $\mathrm{Li}^{+}$. The authors suggested that the absorption peak at $373 \mathrm{~nm}$ due to a free receptor and $333 \mathrm{~nm}$ is due to its cationic complex. The binding ability of metal salts towards receptors completely depends on the cation radius and macrocycle size. 1,8-macrocycle-9,10-anthraquinone derivative $\mathbf{5 9}$ showed a small complexing effect using the UV-vis spectra absorption at $383 \mathrm{~nm}$, probably due to the carbonyl's hindering role groups, as shown in figure 16 [84].

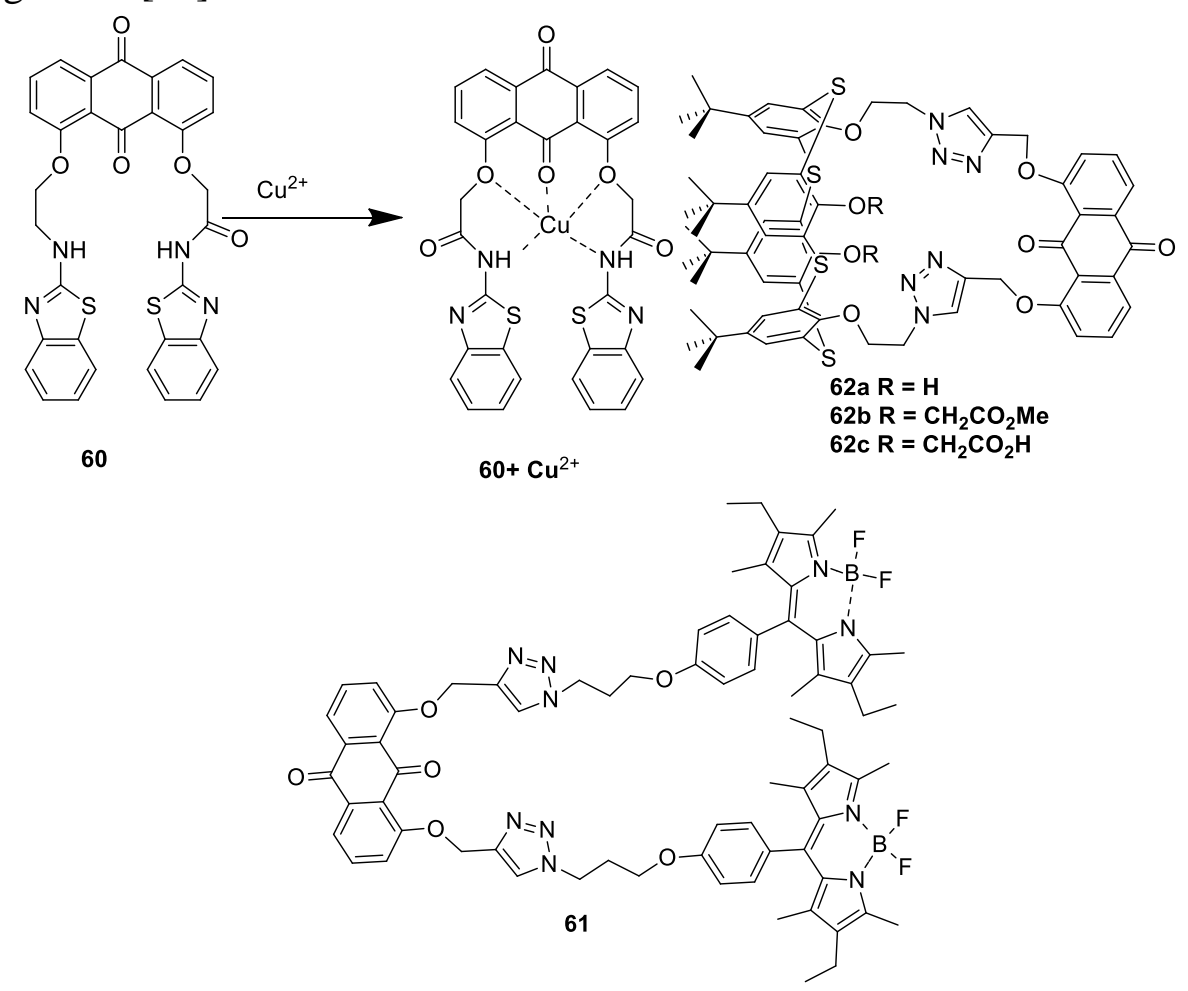

Figure 17. Receptor 60-62 used for sensing properties.

Ghosh and his coworkers have reported an anthraquinone-based molecular receptor $\mathbf{6 0}$ for selective detection of $\mathrm{Cu}^{2+}$ ions using fluorescence titration. Upon excited at $380 \mathrm{~nm}$, the 
emission band was raised at $457 \mathrm{~nm}$. The addition of $\mathrm{Cu}^{2+}$ ions to $\mathbf{6 0}$, gradually quenched the fluorescence emission with a blue shift of $25 \mathrm{~nm}$. The authors found that the receptor $\mathbf{6 0}$ form 1:1 complex with $\mathrm{Cu}^{2+}$ ions with an association constant of $1.77 \times 10^{4} \mathrm{M}-1$. On the other hand, receptor 60 remains silent towards other metal salts [85].

Kursunlu reported a novel triazole tethered Bidipy-anthraquinone receptor 61, as shown in figure 17. For selective detection of $\mathrm{Al}^{3+}$ ions over other metal salts. The receptor showed an absorption band at 212, 290, 400, and $513 \mathrm{~nm}$. The band was observed at $400 \mathrm{~nm}$ due to $\pi-\pi^{*}$ transitions of anthraquinone and Bodipy groups. Upon addition of 20 equiv. of $\mathrm{Al}^{3+}$ ions to $\mathbf{6 1}$, the absorption peak shifted around at 290 and $400 \mathrm{~nm}$. However, receptor $\mathbf{6 1}$ remains silent in the presence of other metal salts. The authors attributed that the selective of $\mathrm{Al}^{3+}$ due to charge transfer from bodily groups to anthraquinone-triazole moiety [86-87]. Gou et al. [88] have reported a series of thiacalix[4]pseudo crown receptors (62a-c) bearing naphthoquinone function for the detection of various metal salts by using UV-vis and fluorescence titrations. From the UV-vis spectra, it was observed that the receptor 62a and $62 \mathbf{b}$ showed absorption bands at 372 and $376 \mathrm{~nm}$, respectively. It is due to anthraquinone moiety. The receptor $\mathbf{6 2 a}$ showed a weak fluorescence emission band at $427 \mathrm{~nm}$ upon excitation at $375 \mathrm{~nm}$. Upon addition of $\mathrm{Pb}^{2+}$ ions, fluorescence enhancement occurred along with a new band raised at 465 $\mathrm{nm}$. The red shift of emission fluorescence was due to ICT mechanism. Under the ideal condition, the receptor remains silent towards other metal salts. From Job's plot, it was observed that receptor form 1: 1 complex with $\mathrm{Pb}^{2+}$ ions. The authors found that the $\mathrm{Pb}^{2+}$ ions strongly interact with the carbonyl group's oxygen and $\mathrm{N}$-atom of the triazole group. Conversely, receptor 62b showed an emission band at $428 \mathrm{~nm}$ upon excitation at $375 \mathrm{~nm}$. Receptor 62 b showed similar behavior towards $\mathrm{Pb}^{2+}$. However, on the addition of $\mathrm{Zn}^{2+}$ to the receptor, fluorescence enhancement ( 3.75 fold) was perceived. A new band occurred at a higher wavelength at $476 \mathrm{~nm}$. The binding constant measurement showed that the receptor formed 1: 1 complex with $\mathrm{Zn}^{2+}$ ions. The receptor remains silent towards other metal salts.

\subsection{Pentaquinones based receptors.}

A series of pentaquinone-based receptors were synthesized by Bhalla and his research group. They exhibited their sensing properties by using UV-vis and Fluorescence spectroscopy. Thiophene tethered pentaquinone receptor 63 exhibited selective and sensitive binding affinities toward $\mathrm{Fe}^{3+}$ and various nitro-aromatics. In THF- $\mathrm{H}_{2} \mathrm{O}(1: 9 \mathrm{v} / \mathrm{v})$, receptor 63 showed absorbance maxima at $415 \mathrm{~nm}, 328 \mathrm{~nm}$, and $300 \mathrm{~nm}$, respectively. In the presence of water, the absorption band intensity increased due to the formation of aggregates of receptor 63 . Upon excitation at $328 \mathrm{~nm}$, receptor 63 showed the emission band at $560 \mathrm{~nm}$. The presence of $\mathrm{Fe}^{3+}$ to 63 leads to quenching the fluorescence emission at $560 \mathrm{~nm}$ [89].

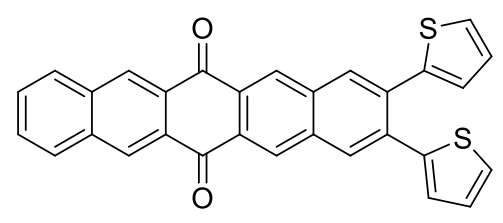

63

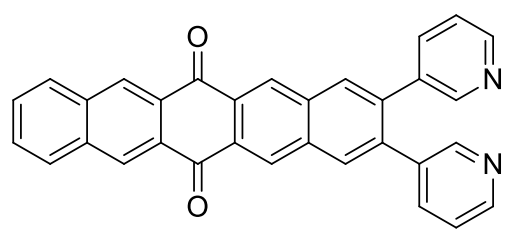

64

Figure 18. Receptor 63-64 used for sensing properties.

The authors found that receptor $\mathbf{6 3}$ used to detect $\mathrm{Fe}^{3+}$ in water, and also in the presence of blood serum milieu. The same groups have also reported nanoaggregates of pentaquinone 
receptor 64 and examined its sensing behavior towards $\mathrm{Pd}^{2+} .64$ displayed the enhancement of the absorption band, followed by quenching the fluorescence intensity. It is occurred due to the formation of a complex between 64 and $\mathrm{Pd}^{2+}$ with nanoaggregates of $\mathbf{6 4}$ as shown in figure 18 [90].

Similarly, the same groups have also reported a series of pentaquinone based receptors 65-66 (Figure 19) to recognize various metal salts by using UV-vis and fluorescence spectroscopy. In THF- $\mathrm{H}_{2} \mathrm{O}$ (9: 1), receptor 65 showed an absorption band at 298 and $403 \mathrm{~nm}$. Receptor 65 underwent hypsochromic shifts in the presence of $\mathrm{Hg}^{2+}$. The enhancement of fluorescence has occurred in the presence of $\mathrm{Hg}^{2+}$. In the presence of $\mathrm{Hg}^{2+} \mathbf{6 5}$ was hydrolyzed and led the fluorescent product 66 [91]. Both receptors were used to detect $\mathrm{Hg}^{2+}$ in blood serum and prostate cancer cell lines.

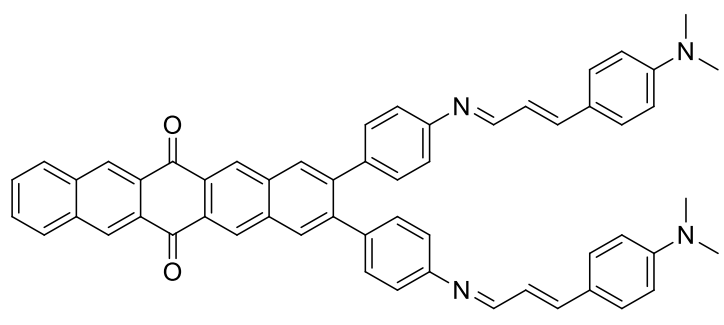

65

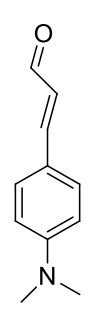

66

Figure 19. Receptor 65-66 used for sensing properties.

Receptor 67a showed weak fluorescence emission at $500 \mathrm{~nm}$ upon excitation at 390 $\mathrm{nm}$. In THF, 67a showed enhancement fluorescence upon addition of 1 equiv. of $\mathrm{Zn}^{2+}$ due to the formation of a complex between $67 \mathbf{a}$ and $\mathrm{Zn}^{2+}$. A similar trend was observed for $67 \mathbf{b}$ [92]. Receptor 68 (Figure 20) endorsed the $\mathrm{Zn}^{2+}$ ions under $\mathrm{F}^{-}$ions triggered a synergistic effect. 68 underwent a fragile fluorescent intensity at $530 \mathrm{~nm}$ upon irradiation $350 \mathrm{~nm}$. In the presence of $\mathrm{Zn}^{2+}$, gradual enhancement of fluorescence intensity was observed. The enhancement of fluorescence emission is due to the formation of the complex between them. The detection limit was calculated from the fluorescence profile and found to be $30 \mathrm{nM}$ [93].
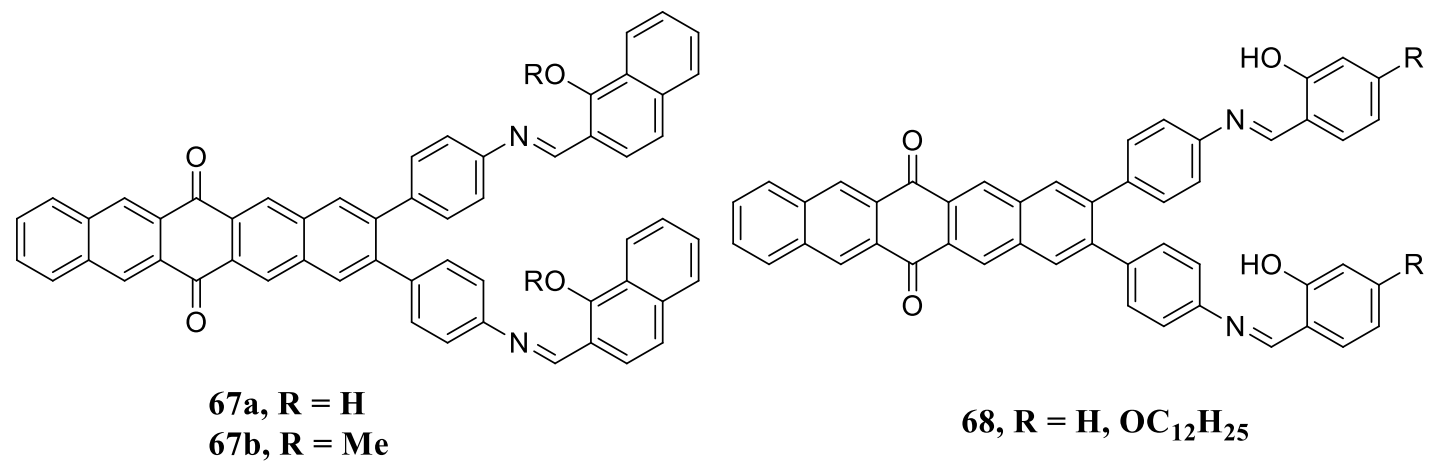

$68, \mathrm{R}=\mathrm{H}, \mathrm{OC}_{12} \mathrm{H}_{25}$

Figure 20. Receptor 67-68 used for sensing properties.

DMSO 69 showed hypochromic shifts along with a new band that occurred at $443 \mathrm{~nm}$. The authors found that the hypochromic absorption band occurred due to the formation of deprotonated species $\mathbf{7 0}$ with $\mathrm{F}^{-}$ions. Absorption band occurred at $443 \mathrm{~nm}$ disappeared, and absorption intensities at $311 \mathrm{~nm}$ increase in the presence of $\mathrm{Cu}^{2+}$, due to the formation of complex 71 [94]. On continued effort on pentaquin one derivatives, the same group reported the rhodamine appended pentaquinone $\mathbf{7 2}$ and 73 (Figure 21). Both receptors were used to detect $\mathrm{Hg}^{2+}$. Upon excitation at $360 \mathrm{~nm}$, receptors showed the emission band at around 572$582 \mathrm{~nm}$ on the addition of $\mathrm{Hg}^{2+}$. It caused the opening of the Spiro lactam ring [95]. 
<smiles>CC(C)CC(=O)Nc1ccc(-c2ccc3cc4c(cc3c2)C(=O)c2cc3ccccc3cc2C4=O)cc1</smiles>

69<smiles>O=C1c2cc3ccccc3cc2C(=O)c2cc3cc(-c4ccc(N5[Al]OC5C(F)(F)F)cc4)ccc3cc21</smiles>

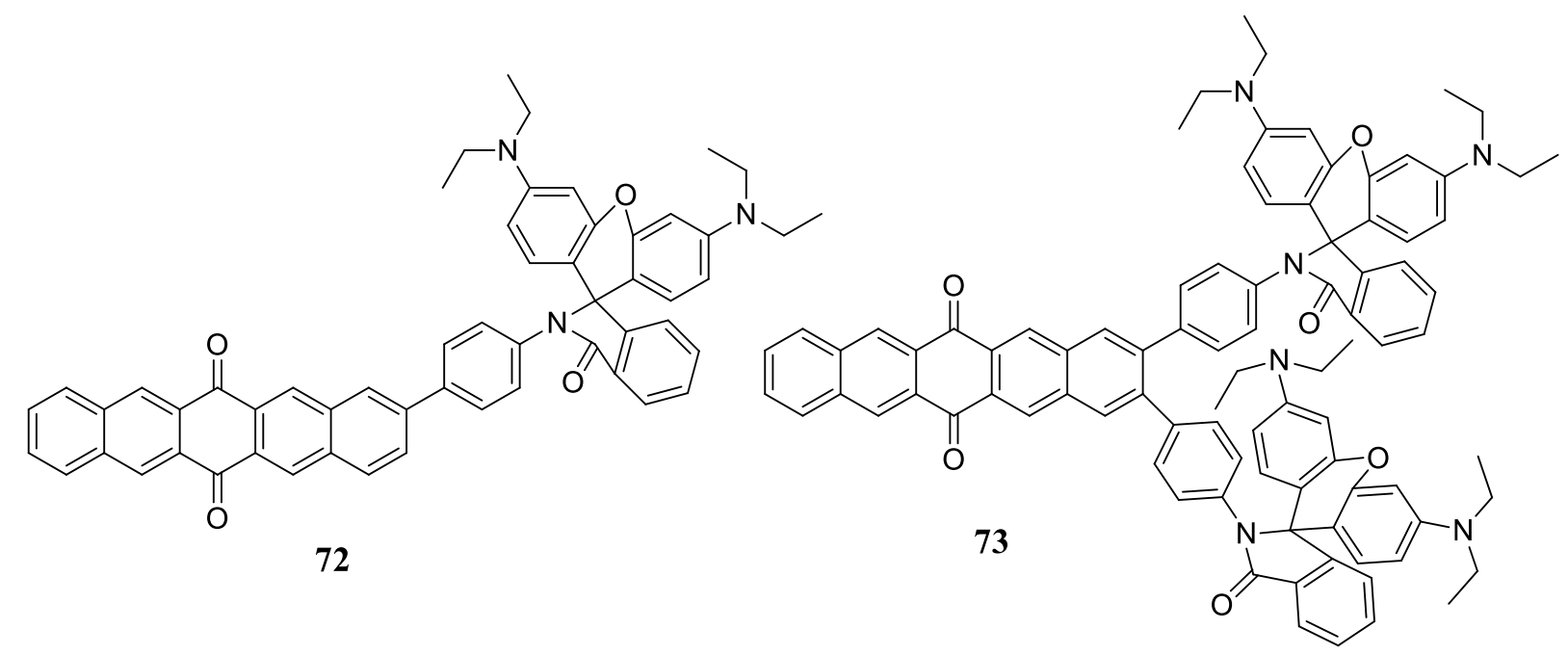

Figure 21. Receptor 69-73 used for sensing properties.<smiles>CN(C)c1ccc(C2=CC(=O)C(=O)c3ccccc32)cc1</smiles>

74<smiles>O=C1C=C(c2ccc(N3CCOCCOCCOCCOCCOCC3)cc2)c2ccccc2C1=O</smiles>

75<smiles>[R]c1ccc2c(c1)C(=O)c1cc([R])ccc1C2=C1SC=CS1</smiles>

76a, $R=\mathbf{H}$

76b, $R=O M e$<smiles>[R]c1ccc2c(c1)C(=S)c1ccc([R])cc1C2=C1SC=CS1</smiles>

$77 \mathbf{a}, \mathbf{R}=\mathbf{H}$

$77 b, R=O M e$

Figure 22. Receptor 74-77 used for sensing properties.

\subsection{Miscellaneous quinone based receptors.}

Highly colored 1,2-naphthoquinone based receptors 74-75 (Figure 22) based on the crown ether group were used as chromogenic chemosensors for metal cations in ACN was reported by Soto and his research group. Both receptors showed absorption intensities at 534 and $532 \mathrm{~nm}$. It was responsible for an intra-ligand charge transfer band involving the amine and the carbonyl groups of receptors. Receptor $\mathbf{7 4}$ was selectively recognized $\mathrm{Cu}^{2+}$ and $\mathrm{Fe}^{3+}$, amongst other metal ions. On the other hand, receptor 75 showed similar behaviors to 74 [40].

Receptors 76a-b and 77a-b were used for selective recognition of $\mathrm{Hg}^{2+}, \mathrm{Cu}^{2+}$ and $\mathrm{Fe}^{3+}$, respectively. The absorption intensities at $579 \mathrm{~nm}$ quenched along with a new band appeared 
at $263 \mathrm{~nm}$ in the presence of $\mathrm{Hg}^{2+}$ and $\mathrm{Cu}^{2+}$ ions. It caused the color change from dark-blue to orange. However, 76a was used to detect $\mathrm{Cu}^{2+}$ and $\mathrm{Fe}^{3+}[96]$. Zhu and his research groups have conveyed an ICT based receptor $\mathbf{7 8}$ for the selective recognition of thiol and the metal ions $\mathrm{Zn}^{2+}$ and $\mathrm{Co}^{2+}$ in $\mathrm{CH}_{3} \mathrm{CN}-\mathrm{H}_{2} \mathrm{O}$. From the UV-vis profile, it was found that the absorption intensities decreased with the appearance of anew absorption band at $394 \mathrm{~nm}$ in the presence of $\mathrm{Zn}^{2+}$ and $\mathrm{Co}^{2+}$ [97].

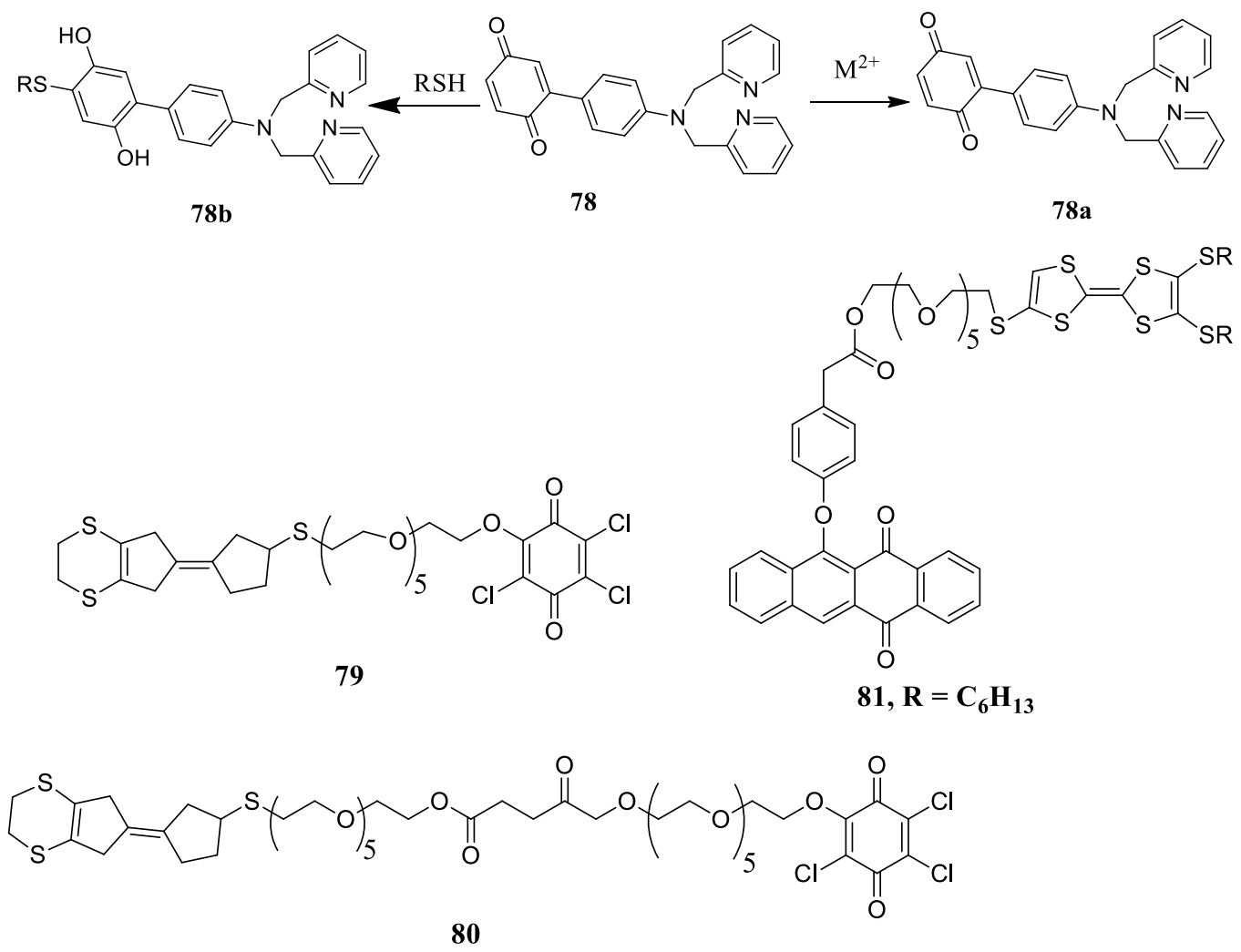

Figure 23. Receptor 78-81 used for sensing properties.

Zhang et al. described phenoxy-quinone the third tetrathiafulvalene derivatives 79-81 (Figure 23) for the sensing of $\mathrm{Pb}^{2+}, \mathrm{Sc}^{3+}$, and $\mathrm{Zn}^{2+}$, respectively [98]. From the UV-vis titrations, it was found that the absorption intensities decreased with the appearance of a set of new absorption bands at 450 and $845 \mathrm{~nm}$. It is due to the electron transfer from TTF to quinone moiety. In UV-vis spectra, receptor $\mathbf{8 1}$ displayed the absorption bands at 450 and $479 \mathrm{~nm}$, respectively. The authors found that in case of the dark condition, $\mathbf{8 1}$ remains silent towards various metal ions; however, in the presence of light, the intensities of absorption band quenched with the appearance of a new absorption band at $790 \mathrm{~nm}$ in the presence of various metal ions such as $\mathrm{Pb}^{2+}, \mathrm{Sc}^{3+}$, and $\mathrm{Zn}^{2+}$, respectively. It is due to the formation of $\mathrm{TTF}^{+}$.

\section{Conclusions}

Fluorescence and colorimetric chemo-sensorial chemistry has grown noticeably after the Nobel Prize in Supramolecular Chemistry to Charles J. Pedersen, Jean-Marie Lehn, and Donald J. Cram. In this review, we have given an overview of the developments of fluorescent and colorimetric indicators built on the quinone scaffold. All the colorimetric and fluorescent sensors were divided into various categories according to their receptors. The results summarized in this review show a clear idea about the important factors such as acceptordonor; size and flexibility piece a noteworthy role in colorimetric and fluorescent sensors, more efficiency and efficacy for detecting specific analytes. We hope this review showed a 
significant role in developing new potent molecular probes for any analytes from cations to anions and small biomolecules that need to be detected, monitored, and visualized. Since quinones already offer an outstanding fluorophores platform. We strongly believe that this research area will become more active due to the biological and environmental implications of various metal salts and anions. Further investigations will continue to increase.

\section{Funding}

Dr. Jali acknowledges a fund from DST, India, by EMEQ project (No.-EEQ/2019/000091). The authors also thank the Department of Chemistry, VSSUT, Burla for providing a research facility.

\section{Acknowledgments}

\section{Dr. Jali thank the Department of Chemistry, VSSUT, Burla for providing a research facility.}

\section{Conflicts of Interest}

The authors have declared that no competing interests exist.

\section{References}

1. Guo, C.; Sedgwick, A.C.; Hiaro, T.; Sessler, J.L. Supramolecular fluorescent sensors: An historical overview and update. Coord. Chem. Rev. 2021, 427, https://doi.org/10.1016/j.ccr.2020.213560.

2. Valeur, B.; Leray, I. Design principles of fluorescent molecular sensors for cation recognition. Coord. Chem. Rev. 2000, 205, 3-40, https://doi.org/10.1016/S0010-8545(00)00246-0.

3. Lehn, J.M.; Eliseev, A.V. Dynamic Combinatorial Chemistry. Science 2001, 291, 2331-2332, https://doi.org/10.1126/science.1060066.

4. Chen, Li.; Liu, D.; Peng, J.; Du, Q.; He, H. Ratiometric fluorescence sensing of metal-organic frameworks: Tactics and perspectives. Coord. Chem. Rev. 2020, 404, https://doi.org/10.1016/j.ccr.2019.213113.

5. Thangadurai, T.D.; Nithya, I.; Rakkiyanasamy, A. Development of three ways molecular logic gate based on water soluble phenazine fluorescent 'selective ion' sensor, Spectrochim. Acta A. 2019, 211, 132-140, https://doi.org/10.1016/j.saa.2018.12.006.

6. Naha, S.; Varalakshmi, A.; Velmathi, S. Nanomolar colorimetric hypochlorite sensor in water. Spectrochim. Acta A. 2019, 220, https://doi.org/10.1016/j.saa.2019.05.028.

7. Pandey, R.; Kumar, A.; Xu, Q.; Pandey, D.S. Zinc(ii), copper(ii) and cadmium(ii) complexes as fluorescent chemosensors for cations. Dalton Trans. 2020, 49, 542-568, https://doi.org/10.1039/C9DT03017D.

8. Lochman, L.; Machacek, M.; Miletin, M.; Uhliŕrová, Š.; Lang, K.; Kirakci, K.; Zimcik, P.; Novakova V. RedEmitting Fluorescence Sensors for Metal Cations: The Role of Counteranions and Sensing of $\mathrm{SCN}^{-}$in Biological Materials. ACS Sens. 2019, 4, 1552-1559, https://doi.org/10.1021/acssensors.9b00081.

9. Zhang, N.; Zhang, D.; Zhao, J.; Xia, Z. Fabrication of a dual-emitting dye-encapsulated metal-organic framework as a stable fluorescent sensor for metal ion detection. Dalton Trans. 2019, 48, 6794-6799, https://doi.org/10.1039/C9DT01125K.

10. Li, H.Y.; Zhao, S.N.; Zang, S.Q.; Li, J. Functional metal-organic frameworks as effective sensors of gases and volatile compounds. Chem. Soc. Rev., 2020, 49, 6364-6401, https://doi.org/10.1039/C9CS00778D.

11. Li, M.; Cui, Z.; Pang, S.; Meng, L.; Ma, D.; Shi, Z.; Feng, S. Luminescent covalent organic framework as a recyclable turn-off fluorescent sensor for cations and anions in aqueous solution. J. Mater. Chem. C 2019, 7, 11919-11925, https://doi.org/10.1039/C9TC03265G.

12. Ye, F.; Wu, N.; Li, P.; Liu, Y.L.; Li, S.J.; Fu. Y. A lysosome-targetable fluorescent probe for imaging trivalent cations $\mathrm{Fe} 3+, \mathrm{Al} 3+$ and $\mathrm{Cr} 3+$ in living cells. Spectrochim. Acta A. 2019, 222, https://doi.org/10.1016/j.saa.2019.117242.

13. Bayindir, S.; Toprak, M. A novel pyrene-based selective colorimetric and ratiometric turn-on sensing for copper. Spectrochim. Acta A. 2019, 213, 6-11, https://doi.org/10.1016/j.saa.2019.01.053.

14. Bayindir, S. A simple rhodanine-based fluorescent sensor for mercury and copper: The recognition of $\mathrm{Hg} 2+$ in aqueous solution, and $\mathrm{Hg} 2+/ \mathrm{Cu} 2+$ in organic solvent. J. Photochem. Photobiol. A. 2019, 372, 235-244, https://doi.org/10.1016/j.jphotochem.2018.12.021.

15. Kamaci, M.; Kaya, I. Polymeric fluorescent film sensor based on poly(azomethine-urethane): Ion sensing and surface properties. React Funct Polym 2019, 136, 1-8, https://doi.org/10.1016/j.reactfunctpolym.2018.12.021. 
16. Podasca, V.E.; Chibac, A.L.; Buruiana, E.C. Fluorescence quenching study of a block copolymer with uracil end units by means of nitroaromatic derivatives and metal cations. J. Mol. Liq. 2019, 292, https://doi.org/10.1016/j.molliq.2019.111385.

17. Jiang, P.; Guo, Z. Fluorescent detection of zinc in biological systems: recent development on the design of chemosensors and biosensors. Coord. Chem. Rev. 2004, 248, 205-229, https://doi.org/10.1016/j.cct.2003.10.013.

18. Nolan, E.M.; Lippard, S.J. Tools and Tactics for the Optical Detection of Mercuric Ion. Chem. Rev. 2008, 108, 3443-3480, https://doi.org/10.1021/cr068000q.

19. Valeur, B.; Leray, I. Design principles of fluorescent molecular sensors for cation recognition. Coord. Chem. Rev. 2000, 205, 3-40, https://doi.org/10.1016/S0010-8545(00)00246-0.

20. Rogers, C.W.; Wolf, M.O. Luminescent molecular sensors based on analyte coordination to transition-metal complexes. Coord. Chem. Rev. 2002, 233, 341-350, https://doi.org/10.1016/S0010-8545(02)00023-1.

21. Chae, M.Y.; Czarnik, A.W. Fluorometric chemodosimetry. Mercury (II) and silver (I) indication in water via enhanced fluorescence signaling. J. Am. Chem. Soc. 1992, 114, 9704-9705, https://doi.org/10.1021/ja00050a085.

22. Bell, T.W.; Hext, N.M. Supramolecular optical chemosensors for organic analytes. Chem. Soc. Rev. 2004, 33, 589-598, https://doi.org/10.1039/B207182G.

23. Martínez-Mánez, R.; Sancenón, F. Fluorogenic and Chromogenic Chemosensors and Reagents for Anions. Chem. Rev. 2003, 103, 4419-4476, https://doi.org/10.1021/cr010421e.

24. Zhou, Y.; Zhang, J.F.; Yoon, J. Fluorescence and colorimetric chemosensors for fluoride-ion detection. Chem. Rev. 2014, 114, 5511-5571, https://doi.org/10.1021/cr400352m.

25. Chen, X.; Pradhan, T.; Wang, F.; Kim, J.S.; Yoon, J. Fluorescent chemosensors based on spiroring-opening of xanthenes and related derivatives. Chem. Rev. 2012, 112, 1910-1956, https://doi.org/10.1021/cr200201z.

26. Kumar, R.; Sharma, A.; Singh, H.; Suating, P.; Kim, H.S.; Sunwoo, K.; Shim, I.; Gibb, B.C.; Kim, J.S. Revisiting Fluorescent Calixarenes: From Molecular Sensors to Smart Materials. Chem. Rev. 2019, 119, 9657-9721, https://doi.org/10.1021/acs.chemrev.8b00605.

27. Czarnik, A.W. Chemical Communication in Water Using Fluorescent Chemosensors. Acc. Chem. Res. 1994, 27, 302-308, https://doi.org/10.1021/ar00046a003.

28. Yuan, L.; Lin, W.; Zheng, K.; He, L.; Huang, W. Far-red to near infrared analyte-responsive fluorescent probes based on organic fluorophore platforms for fluorescence imaging. Chem. Soc. Rev. 2013, 42, 622661, https://doi.org/10.1039/C2CS35313J.

29. Chen, X.; Pradhan, T.; Wang, F.; Kim, J.S.; Yoon, J. Fluorescent Chemosensors Based on Spiroring-Opening of Xanthenes and Related Derivatives. Chem. Rev. 2012, 112, 1910-1956, https://doi.org/10.1021/cr200201z.

30. Wu, H.; Zhang, D.; Su, L.; Ohkubo, K.; Zhang, C.; Yin, S.; Mao, L.; Shuai, Z.; Fukuzumi, S.; Zhu, D. Intramolecular Electron Transfer within the Substituted Tetrathiafulvalene-Quinone Dyads: Facilitated by Metal Ion and Photomodulation in the Presence of Spiropyran. J. Am. Chem. Soc. 2007, 129, 6839-6846, https://doi.org/10.1021/ja0702824.

31. Shibata, H.; Ikeda, Y.; Hiruta, Y.; Citterio, D. Inkjet-printed pH-independent paper-based calcium sensor with fluorescence signal readout relying on a solvatochromic dye. Anal Bioanal Chem. 2020, 412, 34893497, https://doi.org/10.1007/s00216-019-02218-x.

32. Jia, L.; Zhang, G.; Zhang, D.; Xiang, J.; Xu, W.; Zhu, D. A new tetrathiafulvalenephenoxynaphthacenequinone dyad: switching on the intramolecular electron-transfer with UV light irradiation and metal ion coordination. Chem. Commun. 2011, 47, 322-324, https://doi.org/10.1039/C0CC02110E.

33. Boens, N.; Leen, V.; Dehaen, W. Fluorescent indicators based on BODIPY. Chem. Soc. Rev. 2012, 41, 1130-1172, https://doi.org/10.1039/C1CS15132K.

34. Saini, R.; Kaur, N.; Kumar, S. Quinones based molecular receptors for recognition of anions and metal ions. Tetrahedron 2014, 70, 4285-4307, https://doi.org/10.1016/j.tet.2014.04.058.

35. Ghosh, A.; Jose, D.A.; Kaushik, R. Anthraquinones as versatile colorimetric reagent for anions. Sens. Acutators B Chem. 2016, 229, 545-560, https://doi.org/10.1016/j.snb.2016.01.140.

36. Langdon-Jones, E.E.; Pope, S.J.A. The coordination chemistry of substituted anthraquinones: Developments and applications. Coord. Chem. Rev. 2014, 269, 32-53, https://doi.org/10.1016/j.ccr.2014.02.003.

37. Mariappan, K.; Sykes, A.G.J. The chemistry of constrained crown ring systems and fluorescence sensor applications. Inclusion Phenom. Macrocyl. Chem. 2013, 75, 23-30, https://doi.org/10.1007/s10847-0120226-5.

38. Kalyanasundaram, K.; Thomas, J.K. Solvent-dependent fluorescence of pyrene-3-carboxaldehyde and its applications in the estimation of polarity at micelle-water interfaces. J. Phys. Chem. 1977, 81, 2176-2180, https://doi.org/10.1021/j100538a008.

39. Kadarkaraisamy, M.; Sykes, A.G. Luminescence Detection of Transition and Heavy Metals by Inversion of Excited States: Synthesis, Spectroscopy, and X-ray Crystallography of $\mathrm{Ca}, \mathrm{Mn}, \mathrm{Pb}$, and Zn Complexes of 1,8-Anthraquinone-18-Crown-5. Inorg. Chem. 2006, 45, 779-786, https://doi.org/10.1021/ic051672z. 
40. de Silva, A.P.; Gunaratne, H.Q.N.; Gunnlaugsson, T.; Huxley, A.J.M.; McCoy, C.P.; Rademacher, J.T.; Rice, T.E. Signaling Recognition Events with Fluorescent Sensors and Switches. Chem. Rev. 1997, 97, 15151566, https://doi.org/10.1021/cr960386p.

41. Kaur, K.; Kumar, S. 1-Aminoanthracene-9,10-dione based chromogenic molecular sensors: effect of nature and number of nitrogen atoms on metal ion sensing behavior. Tetrahedron 2010, 66, 6990-7000, https://doi.org/10.1016/j.tet.2010.06.031.

42. Kaur, N.; Kumar, S. A differential receptor for selective and quantitative multi-ion analysis for $\mathrm{Co}^{2+}$ and $\mathrm{Ni}^{2+} / \mathrm{Cu}^{2+}$. Tetrahedron Lett. 2008, 49, 5067-5069, https://doi.org/10.1016/j.tetlet.2008.06.023.

43. Ranyuk, E.; Uglov, A.; Meyer, M.; Lemeune, A.B.; Denat, F.; Averin, A.; Beletskaya, I.; Guilard, R. Rational design of aminoanthraquinones for colorimetric detection of heavy metal ions in aqueous solution. Dalton Transactions 2011, 40, 10491-10502, https://doi.org/10.1039/C1DT10677E.

44. Kaur, N.; Kumar, S. Single molecular colorimetric probe for simultaneous estimation of $\mathrm{Cu}^{2+}$ and $\mathrm{Ni}^{2+}$. Chem. Commun. 2007, 3069-3070, https://doi.org/10.1039/B703529B.

45. Kaur, N.; Kumar, S. Aminoanthraquinone-based chemosensors: colorimetric molecular logic mimicking molecular trafficking and a set-reset memorized device. Dalton Trans. 2012, 41, 5217-5224, https://doi.org/10.1039/C2DT12201D.

46. Kaur, N.; Kumar, S. A diamide-diamine based $\mathrm{Cu}^{2+}$ chromogenic sensor for highly selective visual and spectrophotometric detection. Tetrahedron Lett. 2006, 47, 4109-4112, https://doi.org/10.1016/j.tetlet.2006.04.083.

47. Kaur, N.; Kumar, S. Colorimetric metal ion sensors. Tetrahedron 2011, 67, 9233-9264, https://doi.org/10.1016/j.tet.2011.09.003.

48. Kumar, S.; Kaur, N. Nature of 1-(2-aminoethylamino)-anthracene-9, 10-diones - Cu(II) Interactions Responsible for Striking Colour Changes. Supramol. Chem. 2006, 18, 137-140, https://doi.org/10.1080/10610270600564686.

49. Irving, H.; Williams, R.J.P. 637. The stability of transition-metal complexes. Journal of the Chemical Society (Resumed) 1953, 3192-3210, https://doi.org/10.1039/JR9530003192.

50. Kaur, N.; Kumar, S. Colorimetric recognition of $\mathrm{Cu}(\mathrm{II})$ by (2-dimethylaminoethyl)amino appended anthracene-9,10-diones in aqueous solutions: deprotonation of aryl amine NH responsible for colour changes. Dalton Trans. 2006, 3, 3766-3771, https://doi.org/10.1039/B601558A.

51. Kaur, N.; Kumar, S. Near-IR region absorbing 1,4-diaminoanthracene-9,10-dione motif based ratiometric chemosensors for $\mathrm{Cu}^{2+}$. Tetrahedron 2008, 64, 3168-3175, https://doi.org/10.1016/j.tet.2008.01.095.

52. Ermakova, E.; Michalak, J.; Meyer, M.; Arslanov, V.; Tsivadze, A.; Guilard, R.; Lemeune, A.B. Colorimetric Hg2+ Sensing in Water: From Molecules toward Low-Cost Solid Devices. Org. Lett. 2013, 15, 662-665, https://doi.org/10.1021/ol303499v.

53. Ranyuk, E.; Uglov, A.; Meyer, M.; Lemeune, A.B.; Denat, F.; Averin, A.; Beletskaya, I.; Guilard, R. Rational design of aminoanthraquinones for colorimetric detection of heavy metal ions in aqueous solution. Dalton Trans. 2011, 40, 10491-10502, https://doi.org/10.1039/C1DT10677E.

54. Ranyuk, E.; Douaihy, C.M.; Bessmertnykh, A.; Denat, F.; Averin, A.; Beletskaya, I.; Guilard, R. Diaminoanthraquinone-Linked Polyazamacrocycles: Efficient and Simple Colorimetric Sensor for Lead Ion in Aqueous Solution. Org. Lett. 2009, 11, 987-990, https://doi.org/10.1021/ol802926m.

55. Kumar, A.; Vanita, V.; Walia, A.; Kumar, S. N,N-dimethylaminoethylaminoanthrone- A chromofluorogenic chemosensor for estimation of $\mathrm{Cu} 2+$ in aqueous medium and HeLa cells imaging. Sens. Actuators, B Chem. 2013, 177, 904-912, https://doi.org/10.1016/j.snb.2012.11.093.

56. Wu, S.P.; Du, K.J.; Sung, Y.M. Colorimetric sensing of $\mathrm{Cu}(\mathrm{II})$ : $\mathrm{Cu}(\mathrm{II})$ induced deprotonation of an amide responsible for color changes. Dalton Trans. 2010, 39, 4363-4368, https://doi.org/10.1039/B925898A.

57. Wu, S.P.; Huang, R.Y.; Du, K.J. Colorimetric sensing of Cu(II) by 2-methyl-3-[(pyridin-2-ylmethyl)amino]-1,4-naphthoquinone: $\mathrm{Cu}(\mathrm{II})$ induced deprotonation of $\mathrm{NH}$ responsible for color changes. Dalton Trans. 2009, 4735-4740, https://doi.org/10.1039/B822613J.

58. Yang, H.; Zhou, Z.-G.; Xu, J.; Li, F.-Y.; Yi. T.; Huang, C.-H. A highly selective ratiometric chemosensor for $\mathrm{Hg} 2+$ based on the anthraquinone derivative with urea groups. Tetrahedron 2007, 63, 6732-6736, https://doi.org/10.1016/j.tet.2007.04.086.

59. Kim, H.J.; Lee, S.J.; Park, S.Y.; Jung, J.H.; Kim, J.S. Detection of $\mathrm{Cu}^{\mathrm{II}}$ by a Chemodosimeter-Functionalized Monolayer on Mesoporous Silica. Adv. Mater. 2008, 20, 3229-3234, https://doi.org/10.1002/adma.200800246.

60. Chawla, H.M.; Shukla, R.; Pandey, S. Preferential recognition of zinc ions through a new anthraquinonoidal calix[4]arene. Tetrahedron Lett. 2012, 53, 2996-2999, https://doi.org/10.1016/j.tetlet.2012.03.096.

61. Rasheed, L.; Yousuf, M.; Youn, I.S.; Shi, G.; Kim, K.S. An efficient non-reaction based colorimetric and fluorescent probe for the highly selective discrimination of $\mathrm{Pd}^{\circ}$ and $\mathrm{Pd}^{2+}$ in aqueous media. $R S C A d v$. 2016, 6, 60546-60549, https://doi.org/10.1039/C6RA09183K.

62. Yoshida, K.; Mori, T.; Watanabe, S.; Kawai, H.; Nagamura, T.J. Synthesis and metal ion-sensing properties of fluorescent PET chemosensors based on the 2-phenylimidazo[5,4-a]anthraquinone chromophore. Chem. Soc., Perkin Trans. 1999, 2, 393-398, https://doi.org/10.1039/A900424F. 
63. Han, D.Y.; Kim, J.M.; Kim, J.; Jung, H.S.; Lee, Y.H.; Zhang, J.F.; Kim, J.S. ESIPT-based anthraquinonylcalix[4]crown chemosensor for $\mathrm{In}^{3+}$. Tetrahedron Lett. 2010, 51, 1947-1951, https://doi.org/10.1016/j.tetlet.2010.02.006.

64. Okamoto, K.; Fukuzumi, S. An Yttrium Ion-Selective Fluorescence Sensor Based on Metal Ion-Controlled Photoinduced Electron Transfer in Zinc Porphyrin-Quinone Dyad. J. Am. Chem. Soc. 2004, 126, 1392213923, https://doi.org/10.1021/ja045374x.

65. Agarwal, G.; Lande, D.N.; Chakrovarty, D.; Gejji, S.P.; Mirkute, P.G.; Patil, A.; Gawali, S.S. Bromine substituted aminonaphthoquinones: synthesis, characterization, DFT and metal ion binding studies. RSC. Adv. 2016, 6, 88010-88029, https://doi.org/10.1039/C6RA20970J.

66. Parthiban, C.; Manivannan, R.; Elango, K.P. Highly selective colorimetric sensing of $\mathrm{Hg}$ (II) ions in aqueous medium and in the solid state via formation of a novel M-C bond. Dalton Trans. 2015, 44, 3259-3264, https://doi.org/10.1039/C4DT03289F.

67. Jali, B.R.; Masud, K.; Baruah, J.B. Selectivity in changes of fluorescence emission of 1,4-naphthoquinone derivatives by manganese and cadmium ions. Polyhedron 2013, 51, 75-81, https://doi.org/10.1016/j.poly.2012.12.018.

68. Mirkute, P.G.; Patil, A.; Lande, D.N.; Chakravarty, D.; Gejji, S.P.; Satpute, S.; Gawali, S.S. Naphthoquinone based chemosensors for transition metal ions: experiment and theory. RSC Adv. 2017, 7, 55163-55174, https://doi.org/10.1039/C7RA10490A.

69. Wang, Y.; Wang, L.; Shi, L.L.; Shang, Z.B.; Zhang, Z.; Jin, W.J. Colorimetric and fluorescence sensing of $\mathrm{Cu}^{2+}$ in water using 1,8-dihydroxyanthraquinone- $\beta$-cyclodextrin complex with the assistance of ammonia. Talanta 2012, 94, 172-177, https://doi.org/10.1016/j.talanta.2012.03.013.

70. Kar, P.; Suresh, M.; Kumar, D. K.; Jose, D. A.; Ganguly, B.; Das, A. Preferential binding of the magnesium ion by anthraquinone based chromogenic receptors. Polyhedron 2007, 26, 1317-1322, https://doi.org/10.1016/j.poly.2006.10.051.

71. Shamsipur, M.; Poursaberi, T.; Avanes, A.; Sharghi, H. Copper(II)-selective fluorimetric bulk optode membrane based on a 1-hydroxy-9,10-anthraquinone derivative having two propenyl arms as a neutral fluorogenic ionophore. Spectrochim. Acta, Part A: Mol. Biomol. Spectrosc. 2006, 63, 43-48, https://doi.org/10.1016/j.saa.2005.04.013.

72. Park, D.H.; Kang, S.O.; Lee, H.J.; Nam, K.C.; Jeon, S. Synthesis and Electrochemistry of DiesterAnthraquinone as Lithium-Ion Selective Receptor. Bull. Korean Chem. Soc. 2001, 22, 638-640.

73. Kumar, S.; Pramila, K.; Kaur, S. Photoactive chemosensors. Part 1: A 9,10-anthraquinone and 2aminothiophenol based $\mathrm{Cu}(\mathrm{II})$ selective chemosensor. Tetrahedron Lett. 2002, 43, 1097-1099, https://doi.org/10.1016/S0040-4039(01)02333-4.

74. Mariappan, K.; Basa, P.N.; Balasubramanian, V.; Fuoss, S.; Sykes, A.G. Synthesis, reactivity, catenation and $\mathrm{X}$-ray crystallography of $\mathrm{Ag}^{+}$and $\mathrm{Cu}^{+}$complexes of anthraquinone-based selenoethers: A luminescent chemodosimeter for $\mathrm{Cu}^{2+}$ and $\mathrm{Fe}^{3+}$. Polyhedron 2013, 55, 144-154, https://doi.org/10.1016/j.poly.2013.03.003.

75. Young, V.G.; Quiring, H.L.; Sykes, A.G. A Luminescent Sensor Responsive to Common Oxoacids: X-ray Crystal Structure of $\left[\mathrm{H}_{3} \mathrm{O} \cdot 1,8\right.$-Oxybis (ethyleneoxyethyleneoxy)anthracene-9,10-dione $] \mathrm{ClO}_{4}$. J. Am. Chem. Soc. 1997, 119, 12477-12480, https://doi.org/10.1021/ol047847a.

76. Kampmann, B.; Lian, Y.; Klinkel, K.L.; Vecchi, P.A.; Quiring, H.L.; Soh, C.C.; Sykes, A.G. Luminescence and Structural Comparisons of Strong-Acid Sensor Molecules. 2. J. Org. Chem. 2002, 67, 3878-3883, https://doi.org/10.1021/jo0257344.

77. Kadarkaraisamy, M.; Sykes, A.G. Selective luminescence detection of cadmium(II) and mercury(II) utilizing sulfur-containing anthraquinone macrocycles (part 2) and formation of an unusual -crown ether dimer via reduction of $\mathrm{Hg}(\mathrm{II})$ by DMF. Polyhedron 2007, 26, 1323-1330, https://doi.org/10.1016/j.poly.2006.10.046.

78. Basa, P.N.; Bhowmick, A.; Schulz, M.M.; Sykes, A.G. Site-Selective Imination of an Anthracenone Sensor: Selective Fluorescence Detection of Barium(II). J. Org. Chem. 2011, 76, 7866-7871, https://doi.org/10.1021/jo2013143.

79. Kim, H.J.; Kim, S.H.; Kim, J.H.; Anh, L.N.; Lee, J.H.; Lee, C.H.; Kim, J.S. ICT-based Cu(II)-sensing 9,10anthraquinonecalix[4]crown. Tetrahedron $\quad$ Lett. $2009, \quad 50, \quad$ https://doi.org/10.1016/j.tetlet.2009.03.149.

80. Kim, S.H.; Choi, H.S.; Kim, J.; Lee, S.J.; Quang, D.T.; Kim, J.S. Novel Optical/Electrochemical Selective 1,2,3-Triazole Ring-Appended Chemosensor for the $\mathrm{Al}^{3+}$ Ion. Org. Lett. 2010, 12, 560-563, https://doi.org/10.1021/ol902743s.

81. Zhang, Y.J.; He, X.P.; Hua, M.; Li, Z.; Shi, X.X.; Chen, G.R. Highly optically selective and electrochemically active chemosensor for copper (II) based on triazole-linked glucosyl anthraquinone. Dyes Pigments, 2011, 88, 391-395, https://doi.org/10.1016/j.dyepig.2010.08.010.

82. Erk, C.; Erbay, E. Novel Macrocycles. Part 6. Synthesis, Structures and Cation Binding from Optical Spectroscopy of 9,10-Anthraquinone-crown Ethers. J. Inclusion Phenom. Macrocycl. Chem. 2000, 36, 229241, https://doi.org/10.1023/A:1008072926866.

83. Ghosh, K.; Kar, D. Anthraquinone coupled benzothiazole-based receptor for selective sensing of $\mathrm{Cu}^{2+} . J$. Inclusion Phenom. Macrocyclic Chem. 2013, 77, 67-74, https://doi.org/10.1007/s10847-012-0217-6. 
84. Kursunlu, A.N. A fluorescent "turn on" chemosensor based on Bodipy-anthraquinone for $\mathrm{Al}(\mathrm{III})$ ions: synthesis and complexation/spectroscopic studies. RSC Adv., 2015, 5, 41025-41032, https://doi.org/10.1039/C5RA03342J.

85. Zhan, J.; Fang, F.; Tian, D.; Li, H. Anthraquinone-modified calix[4]arene: Click synthesis, selective calcium ion fluorescent chemosensor and INHIBIT logic gate. Supramol. Chem. 2012, 24, 272-278, https://doi.org/10.1080/10610278.2012.656124. (b) Lv, X.-X.; Wang, Q.; Zhang, L.-J.; Lu, L.-L.; Zhao, M.; Guo, D.-S. Synthesis, crystal structure and remote allosteric binding properties of cone thiacalix[4]pseudocrown receptors bearing anthraquinone function and different arms. RSC Adv. 2017, 7, 35528-35536, https://doi.org/10.1039/C7RA06083A.

86. Bhalla, V.; Gupta, A.; Kumar, M. A pentacenequinone derivative with aggregation-induced emission enhancement characteristics for the picogram detection of $\mathrm{Fe}^{3+}$ ions in mixed aqueous media. Dalton Trans. 2013, 42, 4464-4469, https://doi.org/10.1039/C3DT32546F.

87. Bhalla, V.; Gupta, A.; Kumar, M. Fluorescent Nanoaggregates of Pentacenequinone Derivative for Selective Sensing of Picric acid in Aqueous Media. Org. Lett. 2012, 14, 3112-3115, https://doi.org/10.1021/ol301202v.

88. Bhalla, V.; Gupta, A.; Kumar, M. Nanoaggregates of a pentacenequinone derivative as reactors for the preparation of palladium nanoparticles. Chem. Commun. 2012, 48, 11862-11864, https://doi.org/10.1039/C2CC36667C.

89. Bhalla, V.; Roopa; Kumar, M.; Sharma, P.R.; Kaur, T. $\mathrm{Hg}^{2+}$ induced hydrolysis of pentaquinone based Schiff base: a new chemodosimeter for $\mathrm{Hg}^{2+}$ ions in mixed aqueous media. Dalton Trans. 2013, 42, 15063-15068, https://doi.org/10.1039/C3DT51273H.

90. Bhalla, V.; Roopa; Kumar, M. Pentaquinone based probe for nanomolar detection of zinc ions: Chemosensing ensemble as an antioxidant. Dalton Trans. 2013, 42, 975-980, https://doi.org/10.1039/C2DT31341C.

91. Bhalla, V.; Kumar, M. Fluoride Triggered Fluorescence "Turn On" Sensor for $\mathrm{Zn}^{2+}$ Ions Based on Pentaquinone Scaffold That Works as a Molecular Keypad Lock. Org. Lett. 2012, 14, 2802-2805, https://doi.org/10.1021/ol301030z.

92. Liu, R.L.; Lu, H.Y.; Li, M.; Z.Hu S.; Chen, C.F. Simple, efficient and selective colorimetric sensors for naked eye detection of $\mathrm{Hg}^{2+}, \mathrm{Cu}^{2+}$ and $\mathrm{Fe}^{3+} . \quad R S C$ Adv. 2012, 2, 4415-4420, https://doi.org/10.1039/C2RA20385E.

93. Zeng, Y.; Zhang, G.; Zhang, D.; Zhu, D. A dual-function colorimetric chemosensor for thiols and transition metal ions based on ICT mechanism. Tetrahedron Lett. 2008, 49, 7391-7394, https://doi.org/10.1016/j.tetlet.2008.10.055.

94. Jali, B.R.; Baruah, J.B. Fluorescence properties, aluminium ion selective emission changes and selfassemblies of positional isomers of 4-(hydroxyphenylthio) naphthalene-1,2-diones. Dyes Pigments 2014, 110, 56-66, https://doi.org/10.1016/j.dyepig.2014.05.023.

95. Vogtle, F. New ligand systems for ions and molecules and electronic effects upon complexation. Pure Appl. Chem. 1980, 52, 2405-2416, http://dx.doi.org/10.1351/pac198052112405.

96. Kim, J.Y.; Kim, G.; Kim, C.R.; Lee, S.H.; Lee, J.H.; Kim, J.S. UV band splitting of chromogenic azocoupled calix[4]crown upon cation complexation. J. Org. Chem. 2003, 68, 1933-1937, https://doi.org/10.1021/jo020684o.

97. Wu, H.; Zhang, D.; Su, L.; Ohkubo, K.; Zhang, C.; Yin, S.; Mao, L.; Shuai, Z.; Fukuzumi, S.; Zhu, D. Intramolecular Electron Transfer within the Substituted Tetrathiafulvalene-Quinone Dyads: Facilitated by Metal Ion and Photomodulation in the Presence of Spiropyran. J. Am. Chem. Soc. 2007, 129, 6839-6846, https://doi.org/10.1021/ja0702824.

98. Jia, L.; Zhang, G.; Zhang, D.; Xiang, J.; Xu, W.; Zhu, D. A new tetrathiafulvalenephenoxynaphthacenequinone dyad: switching on the intramolecular electron-transfer with UV light irradiation and metal ion coordination. Chem. Commun. 2011, 47, 322-324, https://doi.org/10.1039/C0CC02110E. 